\title{
Bacteriological outcomes following random allocation to quarter-level selection based on California Mastitis Test score or cow-level allocation based on somatic cell count for dry cow therapy
}

\author{
S. McDougall, ${ }^{1,2 *}$ (1) J. Williamson, ${ }^{3}{ }^{\oplus}$ and J. Lacy-Hulbert ${ }^{3} \odot$ \\ ${ }^{1}$ Cognosco, Anexa, Morrinsville, New Zealand, 3300 \\ ${ }^{2}$ School of Veterinary Science, Massey University, Palmerston North, New Zealand, 4442 \\ ${ }^{3}$ DairyNZ Ltd., Newstead, Hamilton, New Zealand, 3221
}

\section{ABSTRACT}

Intramammary infusion of antimicrobials at the end of lactation (dry cow therapy) has been a cornerstone of mastitis management for many years. However, as only a proportion of cows are infected at this time, treating only those cows likely to be infected is an important strategy to reduce antimicrobial usage and minimize risk of emergence of antimicrobial resistance. Such an approach requires the ability to discriminate between cows and quarters likely to be infected and uninfected. This study compared assignment of cows or quarters to antimicrobial treatment at the end of lactation based on cow composite somatic cell count (SCC; i.e., all quarters of cows with a maximum SCC across lactation $>200,000$ cells $/ \mathrm{mL}$ received an antimicrobial; $\mathrm{n}=$ 891 cows, SCC-group) or assignment to quarter-level treatment based on a quarter level California Mastitis Test (CMT) score $\geq$ trace $(\mathrm{n}=884$ cows; CMT-group) performed immediately before drying off. All quarters of all cows also received an infusion of a bismuth-based internal teat sealant. Milk samples were collected for microbiology following the last milking, and again within $4 \mathrm{~d}$ of calving. Clinical mastitis records from dry off to $30 \mathrm{~d}$ into the subsequent lactation were collected. Multilevel, multivariable models were used to assess the effect of assignment to antimicrobial treatment. At drying off, a total of $575(8.8 \%)$ and $147(2.3 \%)$ of the 6,528 quarters had a minor, and a major intramammary infection (IMI), respectively. At drying off, 2089/3270 $(63.9 \%)$ and $883 / 3311(26.7 \%)$ of quarters were treated with dry cow therapy in the CMT and SCC-groups, respectively. Apparent bacteriological cure proportion for any IMI was higher in quarters assigned to the CMT than the SCC-group (349/368 (0.95, 95\% CI

Received July 16, 2021.

Accepted November 22, 2021.

*Corresponding author: smcdougall@anexafvc.co.nz
0.92-0.97) versus 313/346 (0.90, 95\% CI $0.87-0.93))$. New IMI proportion was lower among quarters assigned to the CMT than SCC-group [101/3,212 (0.032, $95 \%$ CI $0.025-0.038)$ versus $142 / 3,232(0.044,95 \%$ CI $0.036-0.051)]$. The prevalence of any IMI postcalving was lower in quarters assigned to the CMT than SCCgroup [119/3,243 (0.037, 95\% CI: 0.030-0.044) versus $173 / 3,265(0.054,95 \%$ CI: $0.045-0.062)]$. There was no difference in incidence of clinical mastitis between treatment groups. The total mass of antimicrobials used was $63 \%$ higher in the CMT-group than in the SCC-group (3.47 versus $2.12 \mathrm{mg} / \mathrm{kg}$ of liveweight). Selection of quarters for antimicrobial treatment at the end of lactation based on CMT resulted in greater proportion undergoing bacteriological cure, reduced risk of any new IMI and reduced post calving prevalence of any IMI compared with selection of cows based on SCC. However, CMT-based selection resulted in higher antimicrobial use compared with SCC-based selection, and further research is required to analyze the cost benefit and impact on risk of antimicrobial resistance of these 2 strategies.

Key words: dry cow therapy, cow-selection, California Mastitis Test

\section{INTRODUCTION}

Due to concerns about antimicrobial use and the risk of selection for resistant pathogens, dairy farmers around the world are under pressure to reduce antimicrobial usage. Treatment of clinical mastitis cases during lactation and infusion of antimicrobials at the end of lactation (dry cow therapy; DCT) constitutes the majority of antimicrobial usage in dairy cows in most dairy industries (Pol and Ruegg, 2007; Compton and McDougall, 2014; Stevens et al., 2016).

Preventing new IMI and treating existing IMI over the nonlactating period is a cornerstone of mastitis control (Dodd et al., 1969). Meta-analyses found a 39\% reduction in the new IMI rate and a $78 \%$ increase in 
cure rate following DCT infusion over the dry period, relative to no DCT (Halasa et al., 2009a,b). However, not all cows and quarters have an IMI at the end of lactation, with the quarter-level prevalence of IMI in relatively recent years reported as ranging between 13 and 61\% (Pantoja et al., 2009; Bradley et al., 2011; Gohary and McDougall, 2018). For cows or quarters likely to be uninfected, infusion of only an internal teat sealant (ITS) containing bismuth subnitrate offers a nonantibiotic approach to reducing the rate of new IMI over the nonlactating period. Infusion of ITS-alone is associated with a rate of new infection equivalent to or lower than infusion of DCT alone (Rabiee and Lean, 2013; Dufour et al., 2019). Additionally, a combination of an ITS and DCT reduces the risk of new IMI over the dry period and reduces the SCC and clinical mastitis incidence in the subsequent lactation compared with DCT alone (Bradley et al., 2011; Golder et al., 2016). Thus, categorizing cows or quarters as likely to be infected or uninfected, and treating likely infected cows or quarters with DCT, and using ITS in likely uninfected cows (selective DCT) provides an approach that may reduce overall antimicrobial usage but minimize new infection rates over the dry period, and SCC and clinical mastitis incidence in the subsequent lactation. However, implementation of selective DCT requires that infected and uninfected cows or quarters can be differentiated.

Cow-composite SCC has traditionally been used to define IMI. A threshold of $>200,000$ cells $/ \mathrm{mL}$ has a sensitivity (Se) and specificity (Sp) of 83.4 and $58.9 \%$, respectively, for identification of a major pathogen IMI, and a Se and Sp of 72.6 and $85.5 \%$, for identification of any IMI where SCC was determined at the same time that microbiological culture was undertaken (Timms and Schultz, 1987; Dohoo and Leslie, 1991). Cow composite SCC, as part of an algorithm-based cow selection for selective DCT, reduced antimicrobial usage by about $60 \%$ without negative effects on cow health or production (Vasquez et al., 2018). However, not all producers measure regular individual cow SCC as part of production recording. For example, only $64.3 \%$ of herds and $65.9 \%$ of cows were production recorded in the 2016/17 lactation in New Zealand. For those herds with no individual cow SCC data, producers and veterinarians commonly treat every quarter of every cow with DCT. However, this results in many cows with truly uninfected quarters being unnecessarily treated with antibiotics, particularly when the bulk milk SCC is low. For these herds, an alternative approach to selecting quarters of cows for DCT is required.

Cow or quarter selection for DCT may also be based on culture of cow-composite or quarter-level milk samples (Cameron et al., 2014; Kabera et al., 2020; Rowe et al., 2020), or following use of measures of intramammary inflammation such as conductivity, lactate dehydrogenase, milk amyloid A, NAGase, or CMT (Timms and Schultz, 1987, Pyörälä, 2003). Selective DCT based on on-farm culture systems have been shown to reduce antibiotic usage by $21 \%$ at cow level, or $48 \%$ at quarter level (Cameron et al., 2014; Godden et al., 2016). However, culture, whether on-farm or in a laboratory, and many of the indirect tests require laboratory support, time or capital expenditure. The CMT is cow-side, provides an immediate result, and is relatively inexpensive financially. The CMT results are commonly reported on a scale of 0 , trace, 1, 2, or 3 (Sargeant et al., 2001). The CMT has moderate Se and Sp (Poutrel and Rainard, 1981; Sanford et al., 2006; Bhutto et al., 2012). When assessed on the day of dry off and using a CMT cut point of $>1$, the Se, Sp, positive predictive value (PPV), and negative predictive value (NPV) were $0.75,0.54,0.38$, and 0.85 , respectively, at cow-level, from 232 cows where the major pathogen IMI prevalence in one or more quarters was $28 \%$ (Rindsig et al., 1979). When assessed at $4 \mathrm{wk}$ before drying off and using an CMT cut point of $>0$, the Se, Sp, PPV, and NPV were 0.81, 0.61, 0.61, and 0.81, respectively, at cow-level (Poutrel and Rainard, 1981). Using a latent class model, the Se was estimated to be $0.86(95 \% \mathrm{CI}=0.73$ to 0.97$)$, and Sp $0.46(95 \% \mathrm{CI}$ $=0.41$ to 0.51$)$ for detection of a major IMI in one or more quarters of cows on the day of drying off using $>0$ as the cutpoint (Sanford et al., 2006). Under New Zealand management systems, the Se, Sp, PPV, and NPV were 1.0, 0.75, 0.05, and 1.0, respectively, for detection of quarters with a major pathogen IMI at drying off using a CMT cut point $\geq$ trace (Gohary and McDougall, 2018). If the cutpoint was increased to $\geq$ 1, the Se, Sp, PPV, and NPV were 0.63, 0.91, 0.08 and 0.99, respectively (Gohary and McDougall, 2018).

A recent United Kingdom study evaluated quarterlevel CMT testing at the end of lactation using a cutpoint of $\geq 1$ or $\geq 2$ to assign cows to antimicrobial dry cow therapy as well as internal teat sealant, with cows below the cutpoint receiving internal teat sealant alone (Swinkels et al., 2021). That study demonstrated substantial reductions in overall antimicrobial use with no effect on prevalence of major pathogen infection at subsequent calving or on clinical mastitis incidence rates compared with cows selection and DCT treatment based on SCC.

The objective of this study was to assess the cure rate of any existing IMI, the incidence of any new IMI over the dry period, the prevalence of any IMI postcalving, the incidence of clinical mastitis, the prevalence of 
elevated $(>200,000$ cells $/ \mathrm{mL})$ SCC at first DHI recording, following allocation to antibiotic DCT following a positive CMT test at quarter-level, compared with allocation to DCT treatment of all 4 quarters in cows with a maximum lactational SCC of $>200,000$ cells/ $\mathrm{mL}$. All cows were also infused in all 4 quarters with an ITS. Overall antimicrobial usage at cow-level for cows assigned to the $2 \mathrm{DCT}$ allocation groups were also compared.

\section{MATERIALS AND METHODS}

Four spring-calving, pasture-based, dairy herds in the Waikato, New Zealand, were enrolled in the study with prior written consent from the producers. Approval for this study was granted by the Animal Ethics Committee of AgResearch (Hamilton, New Zealand) before commencement (study number 14394).

Herds were selected based on undertaking 4 or more production recordings across lactation, keeping treatment records, and willingness to be involved in the study (Table 1). Production recording was undertaken by a commercial herd testing organization (LIC, Hamilton, New Zealand) and SCC was determined using a validated and approved flow cytometry technique (Foss Analytics). All herds were milked twice daily in rotary parlors. Cows were fed predominantly on rye grass ( $\mathrm{Lo}$ lium perenne) and white clover (Trifolium repens) pasture. Supplementary feeding used palm kernel extract, maize silage, or pasture silage.

Cows were selected based on having been confirmed pregnant and not listed for removal from the herd.
Data including calving date, production, SCC, age, and disease event records, were retrieved from on-farm or electronic databases before the study commencement and again $30 \mathrm{~d}$ after the last enrolled cow calved. Cows within each herd were blocked by lactation $(1$, $2,>2$ ) then ranked by the last production recording SCC preceding dry off, and randomly assigned within sequential pairs to be diagnosed and assigned to treatment based on CMT (CMT-group) or assigned to dry off treatment based on production recording SCC data (SCC-group). That is, within each herd and lactation block, and following ranking on most recent DHI SCC, sequential pairs of cows were assigned to the SCC or CMT-groups. Treatment was assigned at the quarterlevel for the CMT-group cows, and at cow-level for the SCC-group cows. Assignment was implemented in an Access database (Microsoft) and the treatment allocation for each cow was included on on-farm worksheets used at the time of drying off. Treatment allocation was not included on any subsequent recording sheets hence technicians involved in on-farm sampling, producers and their staff, and laboratory staff were blinded to treatment allocation thereafter.

On the day of dry off, cows with gross evidence of clinical mastitis (heat or swelling of the mammary quarter or grossly evident changes to the color or composition of the milk), very rough teat-end hyperkeratosis (Mein et al., 2001), or nonfunctional quarters were excluded. A CMT was performed on all quarters of all remaining cows by stripping milk from a quarter into one of 4 circular wells in an CMT paddle (X-Spurt; Shoof International Limited), tilting the tray to approximately

Table 1. Descriptive data for cows in herds enrolled in a study assessing allocation at the end of lactation to dry cow therapy at cow level based on DHI SCC or at quarter level based on California Mastitis Test score

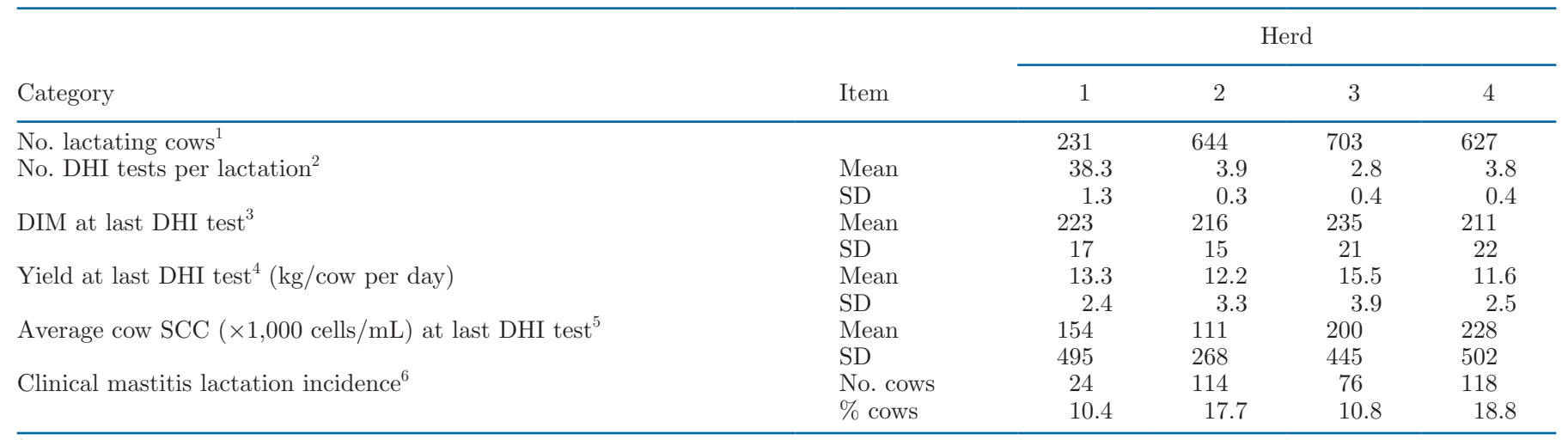

\footnotetext{
${ }^{1}$ Maximum number of lactating cows present in the herd during the lactation preceding drying off.

${ }^{2}$ Average number of DHI tests performed on each cow within each herd across the lactation.

${ }^{3}$ Average number of DIM at the last DHI test of lactation preceding allocation to treatment.

${ }^{4}$ Average cow-level milk solids production (i.e., $\mathrm{kg}$ of milk fat and $\mathrm{kg}$ of milk protein per cow per day) at the last DHI test of the lactation.

${ }^{5}$ Geometric mean SCC of cows within each herd at the last DHI test in lactation.

${ }^{6}$ Cow-level cumulative clinical mastitis incidence rate in the lactation preceding allocation to treatment.
} 
$45^{\circ}$ to horizontal to pour off excess milk to ensure that equal volumes of milk were in each well, squeezing of the reservoir containing a commercially available CMT reagent (RMT reagent RTU, Vetpak Ltd.) built into the handle of the CMT paddle to introduce an approximately equal volume of reagent to milk in each well, gently rotating the paddle for $15 \mathrm{~s}$ and then assessing the degree of gelling visually evident. CMT results were scored on a scale of 0 , trace, 1,2 , and 3 based on the appearance of the milk after mixing with the reagent, where $0=$ no thickening, trace $=$ slight thickening, 1 $=$ distinct thickening but not gel formation, $2=$ immediate thickening followed by gel formation, and 3 = immediate gel formation (Gohary and McDougall, 2018). The CMT scoring was undertaken by one senior, experienced research technician on each farm. A single milk sample $(\sim 2-5 \mathrm{~mL})$ was collected from each quarter of each cow following cleaning of the teat end with a cotton wool ball moistened with $70 \%$ methylated spirits and discard of 3 strips of milk. The milk samples were stored at $-20^{\circ} \mathrm{C}$ before microbiological examination.

For cows allocated to the SCC-group, cows with a maximum SCC at any production recording in the current lactation $>200,000$ cells $/ \mathrm{mL}$ were assigned to be infused into each of the 4 quarters with $500 \mathrm{mg}$ of cloxacillin (Orbenin DC, Zoetis Animal Health), followed with an internal teat sealant (Teatseal, Zoetis Animal Health). For cows assigned to the CMT-group, any quarter that was test-positive (defined as a CMT score $\geq$ trace) was treated with the same dry cow antibiotic and ITS. A cutpoint of $\geq$ trace was selected to maximize the sensitivity of detection of existing IMI as using a cutpoint of $\geq 1$ resulted in a decline sensitivity from 1 to 0.63 in a recent New Zealand study (Gohary and McDougall, 2018). There were concerns that producers and veterinarians would not complete in the study if sensitivity were not maximized by using a cutpoint of $\geq$ trace rather than $\geq 1$. All remaining quarters, such as those from cows with SCC $\leq 200,000$ cells $/ \mathrm{mL}$ throughout the lactation in the SCC-group and any quarters that were CMT-negative in cows in the CMT-group, received the ITS alone. All products were infused using the following the scrubbing of the teat end with cotton wool balls moistened with $70 \%$ methylated spirits, and infusion occurred using the partial insertion method (i.e., the tip of the cannula was placed $\leq 3 \mathrm{~mm}$ into the teat canal). For cows treated with the antibiotic, the teat end was clamped with a thumb and forefinger and the product massaged up into the mammary gland. The ITS was infused following recleaning of the teat end (if dry cow antibiotic treatment had preceded the ITS infusion) and the ITS was not dispersed by massage. Following infusion, the teat ends were sprayed with an iodine-based teat antiseptic. Cows were managed and monitored following normal farm practice over the dry period. For logistics reasons herd owners were not asked to collect milk samples from clinical mastitis cases diagnosed over the dry period.

Within $4 \mathrm{~d}$ of subsequent calving, a single milk sample was collected from each quarter for microbiology by trained research technicians. Producers were asked to collect milk samples from any quarter diagnosed with clinical mastitis up to $30 \mathrm{~d}$ after calving for microbiology, to record all mastitis treatments, and to record date and reason for animals being removed (culled). Drying off occurred between April 20 and May 30, 2018, and the postpartum sampling occurred between June 7 and September 20, 2018. Technicians and producers were trained in the relevant procedures using standard operating procedures.

\section{Laboratory Procedures}

Milk samples collected at drying off were stored for a maximum of $100 \mathrm{~d}$, whereas postpartum samples were stored for a maximum of $55 \mathrm{~d}$. Note that as microbiology was done in batches, the median storage time was less than the maximum time period. Storage at $-20^{\circ} \mathrm{C}$ for up to $16 \mathrm{wk}$ had no effect on the number of samples from which streptococci and Staphylococcus aureus were isolated, and the number of samples from which CNS were isolated increased following storage (Schukken et al., 1989).

Microbiology was undertaken following NMC procedures (Middleton et al., 2017) at the laboratory of DairyNZ Ltd. (Newstead, New Zealand). A quarter was defined as infected when $\geq 2$ cfu of a single bacterial species were found, except for Staph. aureus when $\geq 1$ cfu was defined as an IMI. Using this definition, the Se and Sp of diagnosis of any IMI would be expected to be 60.8 and $91.2 \%$, respectively, whereas for Staph. aureus the Se and Sp would be 90.4 and $99.8 \%$, respectively (Dohoo et al., 2011). Then MALDI-TOF was used to confirm the identity of 26 isolates at drying off and 16 postcalving where the identity could not be confirmed using biochemical testing procedures. This represents less than $5 \%$ of culture positive samples. The majority of the isolates submitted for MALDI-TOF were Grampositive, catalase negative, Streptococci-like isolates. A contaminated sample was defined as presence of $>2$ distinct colony types.

\section{Definitions}

Antimicrobial dry cow therapy is referred to as DCT throughout the paper. Intramammary infections were categorized by pathogen type as minor (i.e., Corynebacterium spp., CNS, others) or major (Escherichia 
coli, Staph. aureus, Streptococcus uberis, Streptococcus dysgalactiae). Cure of any existing IMI was defined as absence of isolation of the pathogen or pathogens isolated at drying off, at the postpartum milk sampling. Failure of cure was defined as presence of the same pathogen present at drying off at the post calving sampling.

A quarter was defined as having a new IMI if it was not infected at drying off but had any IMI postcalving, a pathogen different from that present at drying off was found postcalving, or the quarter was treated for clinical mastitis at any stage between dry off and $30 \mathrm{~d}$ post calving in the subsequent lactation.

All quarters from cows that were treated with antibiotics, anti-inflammatories or corticosteroids (either systemic or intramammary) for reasons other than mastitis preceding the collection of the postpartum samples, or that did not have milk samples collected at postpartum were excluded from analysis. Where samples from one or more quarters within a cow were defined as contaminated, the remaining quarters within the cow remained in the analyses.

A quarter was defined as having clinical mastitis when the producer or a technician found changes in milk composition (i.e., clots, wateriness), or heat or swelling of a quarter within $30 \mathrm{~d}$ after calving. When a quarter was diagnosed with clinical mastitis on multiple occasions, the earliest date of diagnosis for the lactation was used in the subsequent analyses. Data were analyzed at cow and quarter level. For the postpartum clinical mastitis survival analysis, cows were excluded from analysis when the cow died, was euthanized or was removed less than $30 \mathrm{~d}$ postpartum for reasons other than clinical mastitis or when antibiotics, anti-inflammatories or corticosteroids were used less than $30 \mathrm{~d}$ postpartum for reasons other than clinical mastitis and before the diagnosis of clinical mastitis. When treatments other than these are given for reasons other than for clinical mastitis (e.g., for hypocalcemia) the cow remained in this analysis. When a cow died, was euthanized, or was removed for clinical mastitis (irrespective if bacteriological samples are provided) within $30 \mathrm{~d}$ of calving, it was included in the survival analysis as a case.

\section{Statistical Design and Analysis}

Data are presented on an intention-to-treat basis wherever feasible. For example, microbiology data are presented for as many of the cows or quarters available from the microbiology results, whereas the stratification of microbiology data by CMT score, or bacterial cure proportions, are by necessity only reported for cows or quarters for which the CMT data and all microbiol- ogy data were available, respectively. The balance of treatment groups was assessed by using chi-squared analyses (for ordinal or categorical variables) or oneway ANOVA (for continuous variables).

The association between the CMT scores and IMI pathogen type (categorized as no growth, minor or major pathogen) was examined by chi-squared test and by creating receiver operator characteristic (ROC) curves. The area under the curves (AUC) were calculated and compared between CMT score and maximum SCC using nonparametric techniques. The Se, Sp, PPV, and NPV were calculated at the quarter level for presence of any IMI or for a major pathogen IMI using a CMT cutpoint of either $\geq$ trace or $\geq 1$, or cow-composite SCC cutpoint of $>200,000$ cells $/ \mathrm{mL}$ using data from all quarters, irrespective of subsequent treatment allocation group.

Outcome variables included the cure rate of existing infections of any IMI, the rate of new IMI with any pathogen, the prevalence of IMI with any pathogen post-calving all at quarter level, and $\log _{10}$ SCC at first production recording of lactation and clinical mastitis incidence in the dry period and in the first $30 \mathrm{~d}$ of lactation at cow-level.

Initially, univariate models were used to assess the effects of treatment group, herd, lactation (categorized as $1,2,>2$ ), pathogen type at drying off, and front versus rear quarter as independent variables. Factors associated $(P<0.2)$ with the outcome were included in multilevel (quarter within cow), multivariable, random effects logistic regression. First-order interactions between treatment group and other remaining main effects were tested and included if $P<0.05$. Herd and treatment group were considered fixed effects and included in all models. A second model for each outcome variable was then run, taking the final model as above, then forcing in the interaction of maximum SCC in the preceding lactation, categorized as $\leq 200,000$ cells/ $\mathrm{mL}$ or $>200,000$ cells/mL. Estimated marginal means and $95 \%$ confidence intervals $(\mathbf{C I})$ or standard error of the means (SEM) were calculated, having adjusted for confounders in the model.

The $\log _{10}$ SCC at the first production recording of the subsequent lactation was analyzed by generalized linear regression with herd, treatment group, lactation number, weeks in milk at the time of recording (categorized as 1, 2, 3, 4, >4), and bacterial pathogen at drying off (coded at cow level as $0=$ no growth in all 4 quarters, $1=$ minor pathogen growth in one or more quarters, or $2=$ major pathogen growth in one or more quarters and irrespective of presence or absence of minor pathogen infections). First-order interactions were tested as outlined above. Comparisons among 
levels of each variable were undertaken using the Bonferroni adjustment for multiple comparisons. Additionally, cows were categorized as having an SCC at first postpartum production recording of $\leq 200,000$ cells $/ \mathrm{mL}$ or $>200,000$ cells $/ \mathrm{mL}$ and this outcome was analyzed using a random effects logistic regression model with treatment, herd, lactation number, week in milk at first production recording, pathogen at drying off, and maximum SCC in the preceding lactation (categorized as $\leq 200,000$ versus $>200,000$ cells $/ \mathrm{mL}$ ) as main effects. Estimated marginal means and SEM were calculated.

As the incidence of clinical mastitis over the dry period was low, the effect of treatment group on the proportion of cows diagnosed was assessed using chisquared test only. The cumulative incidence of clinical mastitis in the first $30 \mathrm{~d}$ of lactation at cow level was analyzed using a generalized linear mixed model with treatment group and bacteria present at drying off (categorized as no growth in all 4 quarters, a minor pathogen in one or more quarters, a major pathogen in one or more quarters) as explanatory variables. Herd was treated as a random effect. The first order interaction of these variables was tested and found to be not significant $(P>0.2)$. From this model, the estimated marginal means of the treatment effect, and the difference in the incidence of clinical mastitis and the $95 \%$ CI were estimated. Additionally, the hazard of clinical mastitis being detected in the first $30 \mathrm{~d}$ of lactation at cow level for all cows was assessed using survival analyses. Initially Kaplan Meier analyses were performed, and the effect of explanatory variables assessed using a log rank test. Explanatory variables included treatment, herd, maximum SCC in lactation $(\leq 200,000$ vs. $>200,000$ cells $/ \mathrm{mL}$ ), presence of a bacterial pathogen within the cow, and the length of the dry period (categorized as $\leq 100$ vs. $>100 \mathrm{~d}$ ). Those variables associated $(P<0.2)$ were then included in a Cox's proportional hazard analysis. Herd was included as a frailty term to account for cows being nested within herd. Variables were included in the final model where $P<0.05$. The first-order interactions between treatment group and remaining effects were tested and not found to be significant $(P>0.05)$. The assumption of proportional hazard was tested using Schoenfeld residuals and no violation of the hazard's assumption was found $(P=$ 0.98). The association between IMI postcalving and the risk of clinical mastitis at quarter level for the first 30 $\mathrm{d}$ of lactation was examined using a multilevel logistic regression model with IMI presence or absence, herd, and quarter position (front vs. rear) as the main effects.

Total antimicrobial use was calculated using the population-corrected unit approach (Collineau et al., 2017). Briefly the total mass of antimicrobials used for each treatment group at the time of drying off (i.e., number of tubes of cloxacillin used $\times 500 \mathrm{mg}$ ) and the total mass of antimicrobials used for treating clinical mastitis in the dry period and in the first $30 \mathrm{~d}$ of lactation were summed. The average weight of enrolled cows was assumed to be $459 \mathrm{~kg}$ [i.e., the weighted average of the proportion of Friesians (53.9\%), crossbreds (43.2\%), and Jerseys (2.9\%) multiplied by the New Zealand dairy industry average weight of these breeds of 471 , 447, and $403 \mathrm{~kg}$, respectively; https://www.dairynz .co.nz/publications/dairy-industry/new-zealand-dairy -statistics-2019-20/]. The sum of the mass of antimicrobials used per treatment group was then divided by the number of cows in each treatment group times the average weight per cow to calculate the milligrams of antimicrobials used per kilogram live weight for cows in each treatment group.

A priori it was assumed that $10 \%$ of cows in the SCC-group would be diagnosed with clinical mastitis within $30 \mathrm{~d}$ of calving, that the acceptable difference (delta) was $4 \%$, with a power of $80 \%$ and declaring significance at $P<0.05$, then 696 cows per treatment group were required. Allowing for $10 \%$ loss to followup, and $10 \%$ for clustering (that is cows are clustered within herd), then approximately 1,820 cows in total were required. All analyses were undertaken in STATA s/e, version 15.1 (STATA Corp.).

\section{RESULTS}

\section{Balance of Treatment Group and Fate of Cows}

A total of 1,775 cows were eligible, 884 in the CMTgroup and 891 in the SCC-group. There was no difference in distribution of breed, lactation number, or cow clinical mastitis lactational incidence in the preceding

Table 2. Number of cows by breed, lactation number, and clinical mastitis history for cows allocated to treatment at the end of lactation, based on California Mastitis Test (CMT) at quarter level or SCC at cow level, respectively

\begin{tabular}{lrrc}
\hline Category & $\begin{array}{c}\text { CMT } \\
\text { group }\end{array}$ & $\begin{array}{c}\text { SCC } \\
\text { group }\end{array}$ & $P$-value \\
\hline Breed & & & \\
$\quad$ Friesian & 474 & 483 & 0.737 \\
Crossbred & 387 & 380 & \\
$\quad$ Jersey & 23 & 28 & \\
Lactation number & & & \\
$\quad$ ( & 199 & 203 & 0.976 \\
2 & 163 & 161 & \\
$\quad 2$ & 522 & 527 & \\
Clinical mastitis & & & \\
$\quad$ No & 812 & 829 & 0.344 \\
$\quad$ Yes & 72 & 62 & \\
\hline
\end{tabular}


Table 3. Mean and SD of the $\log _{10}$ SCC at the last production recording, $\log _{10}$ SCC of the maximum SCC throughout the lactation, interval (d) from the last production recording to day of drying off, milk yield for cows at the last production recording, and number of days dry ${ }^{1}$ for cows allocated to treatment based on California Mastitis Test (CMT) at quarter level or SCC at cow level

\begin{tabular}{|c|c|c|c|c|c|}
\hline \multirow[b]{2}{*}{ Item } & \multicolumn{2}{|c|}{ CMT group } & \multicolumn{2}{|c|}{ SCC group } & \multirow[b]{2}{*}{$P$-value } \\
\hline & Mean & $\mathrm{SD}$ & Mean & $\mathrm{SD}$ & \\
\hline $\log _{10}$ last SCC & 1.9 & 0.5 & 1.9 & 0.5 & 0.458 \\
\hline $\log _{10}$ maximum SCC & 2.0 & 0.5 & 2.1 & 0.5 & 0.258 \\
\hline Days from last recording to dry off & 59.3 & 17.4 & 59.6 & 16.7 & 0.671 \\
\hline Yield last recording $(\mathrm{kg} / \mathrm{cow}$ per $\mathrm{d})$ & 12.7 & 3.7 & 12.6 & 3.8 & 0.811 \\
\hline Days dry & 84.2 & 22.0 & 84.7 & 21.6 & 0.595 \\
\hline
\end{tabular}

${ }^{1}$ Interval in days from drying off to subsequent calving.

lactation between treatment groups (Table 2). Neither was there a difference in the $\log _{10}$ of the SCC at the last production recording or the maximum SCC across lactation, the interval from last production recording to drying off, the milk yield at the last production recording, or the days dry (Table 3 ).

A total of $74(8.4 \%)$ and $69(7.7 \%)$ cows eligible for the CMT-group and the SCC-group, respectively, were excluded, culled, or died between the time of treatment and $30 \mathrm{~d}$ postpartum (Table 4 ). There were no adverse events deemed to be associated with treatment.

\section{Microbiology}

At dry off, $575(8.8 \%)$ and $146(2.3 \%)$ out of 6,528 quarters were infected with a minor, or major IMI, respectively. Coagulase-negative staphylococci and Corynebacterium spp. were the most common isolates (Table 5). The frequency distribution of bacterial species did not differ between treatment groups at drying off $(P=0.47$; Table 5$)$. A similar proportion of major pathogen-infected quarters were allocated to each treatment group: $71 / 367(19.3 \%)$ versus $75 / 347$ (21.6\%) major pathogen IMI/total IMI to CMT-group and SCC-group respectively $(P=0.45)$.

\section{CMT Score, SCC, and Treatment Allocation}

Among the cows allocated to the CMT group, fewer cows with a maximum SCC $\leq 200,000$ cells $/ \mathrm{mL}$ were treated in all 4 quarters with DCT than cows with a maximum SCC $>200,000$ cells $/ \mathrm{mL}(P<0.001)$. The percentage of cows CMT-positive and treated with DCT in $0,1,2,3$, or 4 quarters was $19.1,14.7,15.9$, 12.6 , and $37.8 \%$ respectively among those cows with a maximum SCC $\leq 200,000$ cells $/ \mathrm{mL}$, whereas $6.3,9.4$, $14.8,17.5$, and $52.0 \%$ of quarters were CMT positive and treated with DCT treated among those cows with a maximum SCC >200,000 cells $/ \mathrm{mL}$.
The distribution of CMT scores differed among quarters with no growth, minor or major pathogen IMI $(P<$ 0.001; Figure 1). Both CMT score and maximum SCC were predictive of major pathogen IMI $(P<0.001)$, and the AUC for CMT did not differ from that for maximum SCC $[$ AUC $=0.84$ (95\% CI: $0.81-0.87)$ vs. $\mathrm{AUC}=0.84$ (95\% CI: 0.81-0.87); $P=0.86$; Figure 2].

The Se, Sp, PPV, and NPV for diagnosing an IMI or a major pathogen IMI for a CMT cutpoint of $\geq$ trace or $\geq 1$, or for a cow composite SCC cutpoint of $>200,000$ cells $/ \mathrm{mL}$ are presented in Table 6 .

The AUC did not differ between cows with a maximum SCC of $\leq 200,000$ cells $/ \mathrm{mL}$ compared with those cows with a maximum SCC $>200,000$ cells $/ \mathrm{mL}[0.78$ (95\% CI: $0.68-0.87)$ vs. 0.80 (95\% CI $0.76-0.83)]$. Numerically, the Se was lower and the Sp higher in

Table 4. Number of cows lost to follow-up between treatment and $30 \mathrm{~d}$ postpartum by treatment allocation group for cows allocated to treatment based on California Mastitis Test (CMT) at quarter level or SCC at cow level

\begin{tabular}{lcc}
\hline Category & $\begin{array}{c}\text { CMT } \\
\text { group }\end{array}$ & $\begin{array}{c}\text { SCC } \\
\text { group }\end{array}$ \\
\hline Misidentification & 2 & 2 \\
Incorrect treatment & 1 & 1 \\
Calved after end of sampling period & 19 & 24 \\
Culled & & \\
Cancer & 1 & 1 \\
Not pregnant & 21 & 6 \\
Johne's disease & 1 & 2 \\
Died & & 3 \\
Johne's disease & 0 & 2 \\
Calving trouble & 4 & 1 \\
Theileria & 0 & 3 \\
Injury & 2 & 1 \\
Renal disease & 0 & 0 \\
Lame & 2 & 2 \\
Milk fever & 2 & 4 \\
Other causes & 3 & 17 \\
Missing at postpartum sampling & 16 & 69 \\
Total & 74 & 7.7 \\
\% of enrolled & 8.4 & \\
\hline
\end{tabular}


Table 5. Number and percentage of culture results at quarter level following sampling on the day of drying off, and in the first $4 \mathrm{~d}$ postpartum among quarters assigned to be treated based on California Mastitis Test (CMT) score at quarter-level at drying off or based on maximum cowlevel SCC during the preceding lactation ${ }^{1}$

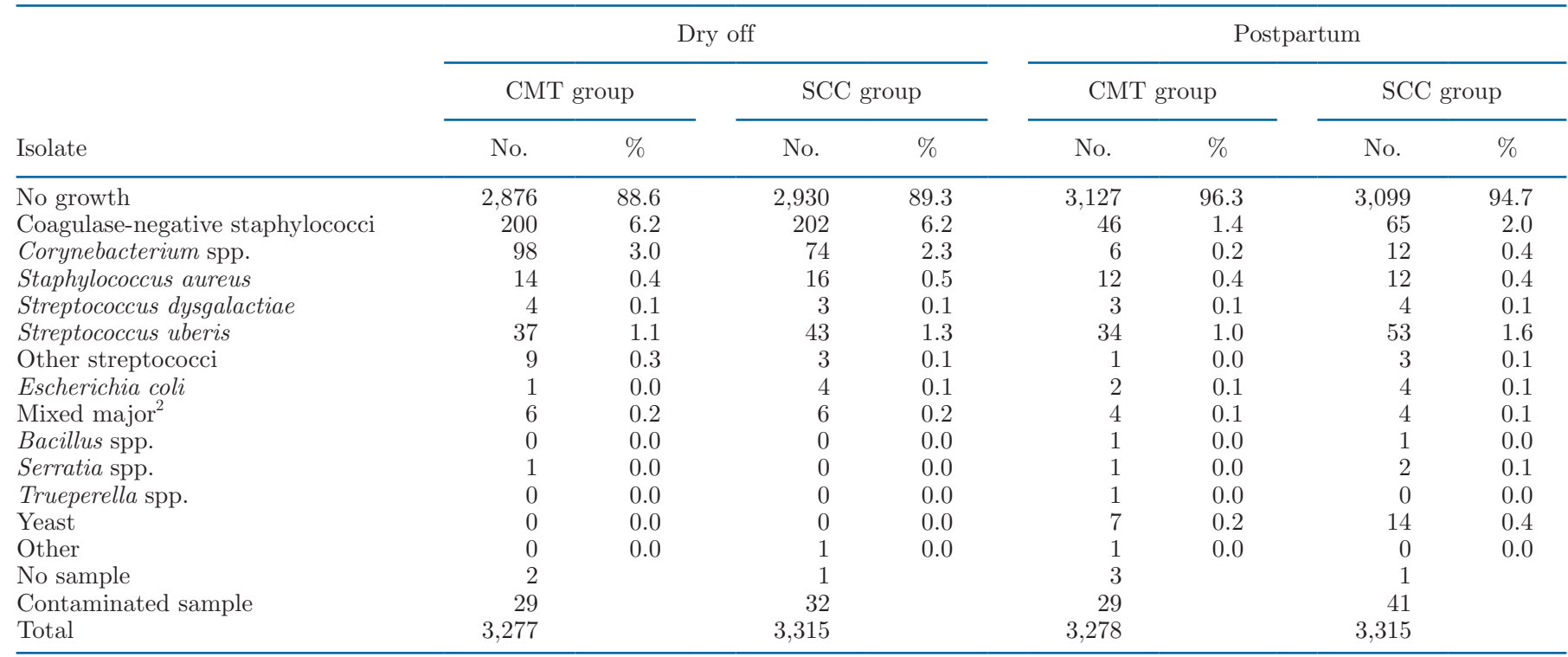

${ }^{1}$ Percentage calculated having excluded samples that were defined as contaminated or where no sample was available.

${ }^{2}$ Isolation of either 2 major pathogens or a major and a minor pathogen from the same quarter.

cows with an SCC $\leq 200,000$ cells/mL compared with $>200,000$ cells $/ \mathrm{mL}(\mathrm{Se}=88.9 \%$ and $\mathrm{Sp}=41.4 \%$ vs. Se $=97.5 \%$ and $\mathrm{Sp}=27.3 \%$, respectively) for CMT tests with a cut-point of $\geq$ trace.

The number of quarters treated with ITS-alone or DCT plus ITS by treatment group is listed in Table 7 . Only 2 and 16 quarters, respectively, in the CMT-group and SCC-group were infected with a major pathogen and not treated with DCT plus ITS (Table 7). Among

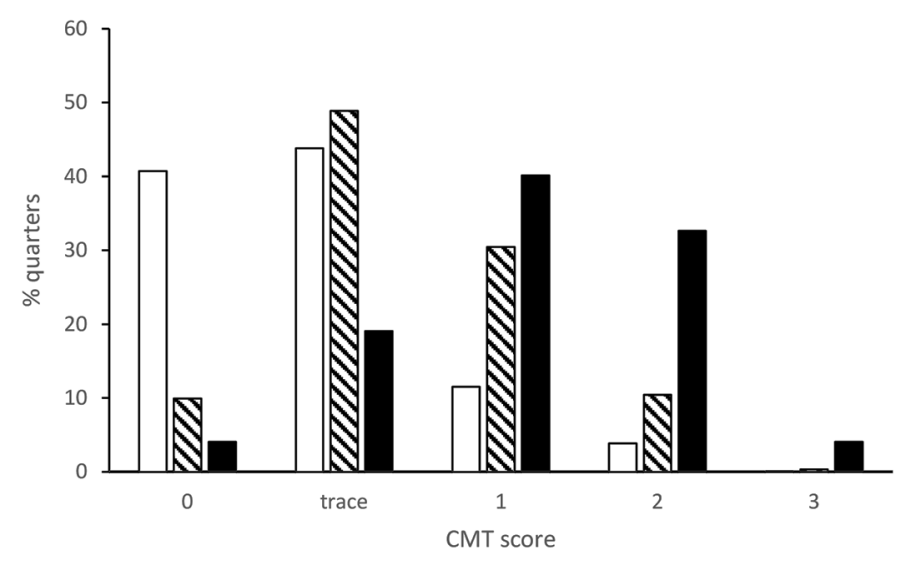

Figure 1. Frequency distribution of California Mastitis Test (CMT) score for 6,516 quarters at drying-off by IMI category: no growth (open bar), minor pathogen (hatched bar; i.e., coagulase-negative staphylococci, Corynebacterium spp., other), or major pathogen (solid bar; Escherichia coli, Staphylococcus aureus, Streptococcus dysgalactiae, Streptococcus uberis). quarters infected with any pathogen, a greater proportion were treated with DCT plus ITS in the CMT-group than in the SCC-group [330/368 (89.7\%) vs. $203 / 347$ (58.5\%); $P<0.001]$.

\section{Cure of Existing Infection}

The bacteriological cure proportion for any IMI was higher for quarters allocated to the CMT-group than

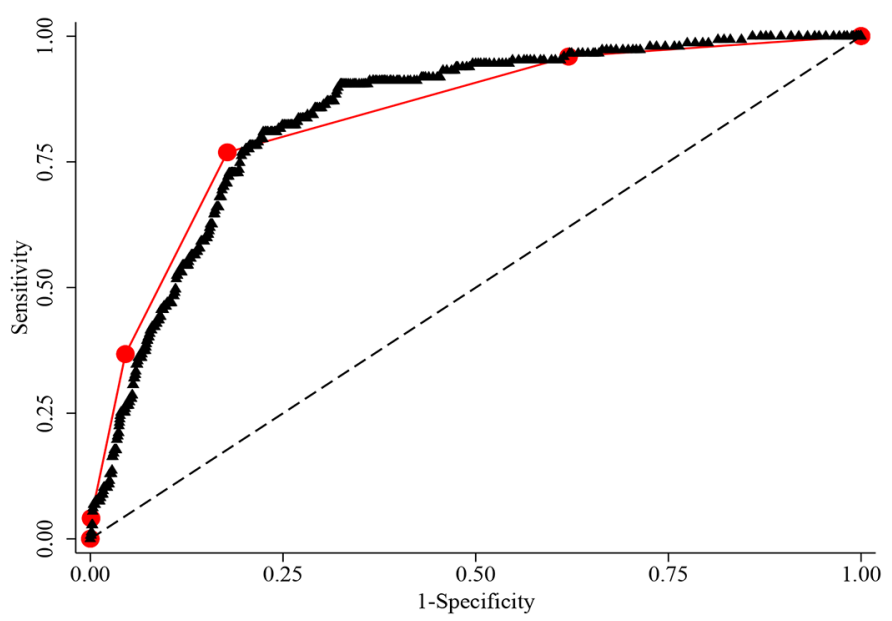

Figure 2. Receiver operating curve for California Mastitis Test (circle) and maximum SCC (triangle) for prediction of presence of a major (i.e., Escherichia coli, Staphylococcus aureus, Streptococcus dysgalactiae, Streptococcus uberis) IMI at drying off for 6,516 quarters. The diagonal dashed line is the reference line. 


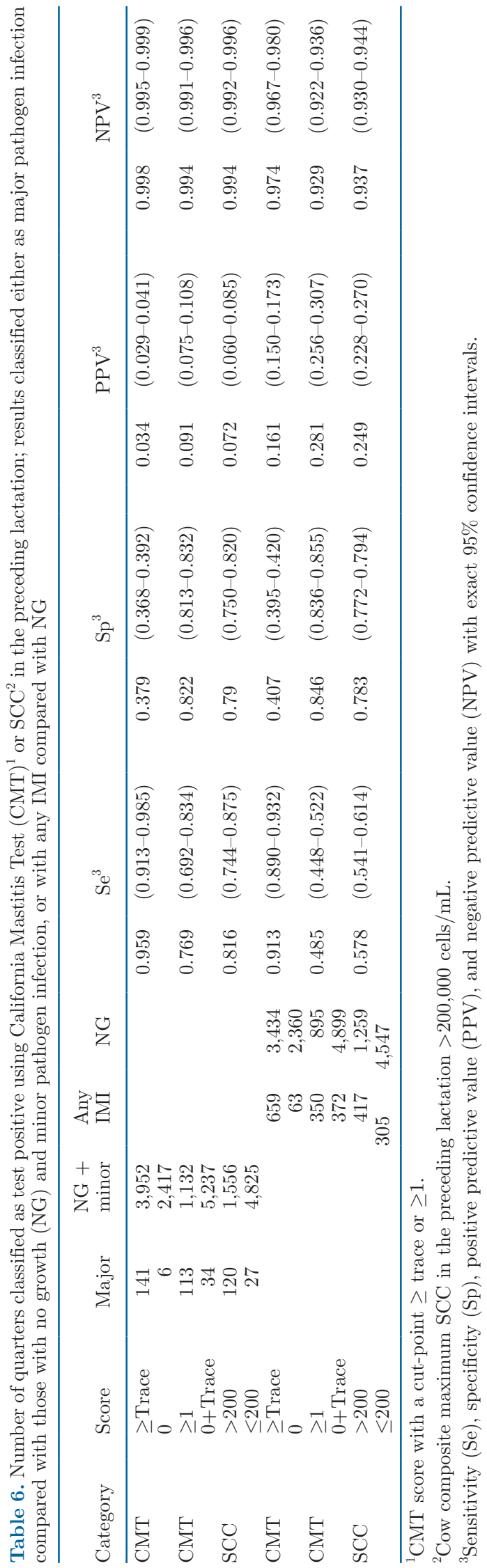

the SCC-group [349/368 (0.95, 95\% CI: 0.92-0.97) vs. 313/346 (0.90, 95\% CI: 0.87-0.93), $P=0.048$; Table 8]. Quarters infected with a minor pathogen had a higher bacteriological cure proportion than those infected with a major pathogen [0.95 (95\% CI: $0.93-0.97)$ vs. 0.82 (95\% CI: $0.75-0.89), P=0.004]$. Cure proportion also tended to vary among herds $(P=0.09)$. There were no interactions between treatment group and type of bacteria isolated at drying off. Due to a $100 \%$ cure proportion in the CMT-group in one herd, models testing the herd by treatment interaction failed to converge.

The bacteriological cure proportion for any IMI did not differ between treatment allocation group within the treatment given. That is, the cure proportion for any IMI was the same for quarters treated with ITS-alone whether ITS had been allocated following a negative CMT test or because the cow had a maximum SCC $\leq 200,000$ cells $/ \mathrm{mL}$ (the 2 bars on the left in Figure 3a). Similarly, the bacteriological cure rate did not differ among quarters treated with ITS plus DCT, irrespective of whether the quarter had been assigned to receive this treatment based on a positive CMT test or a maximum SCC $>200,00$ cells/ $\mathrm{mL}$ (the 2 right-hand bars in Figure $3 \mathrm{a}$ ). In the SCCgroup quarters allocated to ITS-alone as they had a maximum SCC $\leq 200,000$ cells $/ \mathrm{mL}$ (solid bar in the right-hand panel of Figure 3b) had a lower bacteriological cure proportion for any IMI than for quarters of cows allocated to DCT plus ITS alone as they had a maximum SCC $>200,000$ cells $/ \mathrm{mL}$ (hatched bar in the right-hand panel of Figure 3b), and a lower bacteriological cure proportion than quarters of cows in the CMT-group with a $\mathrm{SCC} \leq 200,000$ cells $/ \mathrm{mL}$ (solid bar in left-hand panel of Figure 3b) or a SCC $>200,00$ cells $/ \mathrm{mL}$ (hatched bar in left-hand panel of Figure $3 \mathrm{~b})$. Note that in Figure $3 \mathrm{~b}$ the actual treatment in the CMT group is not explicit as quarters that were CMT positive both among those cows with a SCC $\leq 200,000$ cells $/ \mathrm{mL}$ (solid bar) and among those with a maximum $\mathrm{SCC}>200,000$ cells $/ \mathrm{mL}$ (hatched bar) were treated with ITS plus DCT. Among cows with a maximum SCC $\leq 200,000$ cells/mL, 138/145 (0.97) of the minor IMI were cured, and 13/14 (0.93) of major IMI were cured in the CMT-group. In comparison, 114/131 (0.87) and 10/12 (0.83) of minor and major IMI were cured in the SCC-group, respectively, which by design were treated with ITS-alone.

\section{Incidence of New IMI}

There was a lower new IMI proportion for any IMI in quarters in the CMT-group than in the SCC-group $[101 / 3,212(0.032,95 \%$ CI: $0.025-0.038)$ vs. $142 / 3,232$ (0.044, 95\% CI: 0.036-0.051), $P=0.016$; Table 9]. Fore 
Table 7. Number of quarters allocated to be treated with internal teat sealant (ITS) or dry cow therapy (DCT) + ITS by IMI status at drying off $^{1}$

\begin{tabular}{|c|c|c|c|c|c|c|}
\hline \multirow[b]{2}{*}{ CMT score } & & & \multicolumn{4}{|c|}{ SCC group } \\
\hline & No growth + minor & Major & No growth + minor & Major & No growth + minor & Major \\
\hline 0 & 1,162 & 2 & 1,024 & 1 & 231 & 3 \\
\hline Trace & 1,418 & 9 & 1,069 & 7 & 333 & 12 \\
\hline 3 & 2 & 4 & 1 & 3 & 2 & 0 \\
\hline Total ITS & 1,164 & & 2,411 & & & \\
\hline Total DCT+ITS & 2,074 & & & & 867 & \\
\hline
\end{tabular}

${ }^{1}$ Quarters from cows in the California Mastitis Test (CMT) group were diagnosed and treated at quarter level with ITS where the CMT score $=0$; quarters with a CMT score $\geq$ trace were treated with DCT + ITS. In the SCC group, cows were allocated to ITS alone if they had a maximum SCC $\leq 200,000$ cells $/ \mathrm{mL}$ and no history of clinical mastitis and allocated to the DCT + ITS if they had a maximum SCC $>200,000$ cells $/ \mathrm{mL}$ or a history of clinical mastitis.

quarters were less likely to acquire new IMI than rear quarters [0.027 (95\% CI: $0.021-0.033)$ vs. 0.049 (95\% CI: 0.041-0.056), $P<0.001]$. First and second lactation animals had fewer new IMI than third or greater lactation cows [0.022 (95\% CI: 0.014-0.030), 0.024 (95\% CI: $0.015-0.033)$, and $0.048(0.041-0.056)$ for first, second, and third and subsequent lactations, respectively; $P<$ 0.001]. The new IMI proportion varied among herds $(P$ $<0.001$ ). There were no interactions between treatment group and herd, lactation number, or quarter position. The rate of new IMI was not associated with IMI at drying off $[212 / 5,730(3.7 \%), 26 / 568(4.6 \%)$, and 5/145 (3.8\%) new IMI in quarters that were no growth, infected with a minor pathogen, or infected with a major pathogen at drying off $P=0.57]$. Quarters of cows in the CMT-group which also had a maximum SCC $\leq 200,000$ cells $/ \mathrm{mL}$ had a lower incidence of new IMI than cows in the SCC and CMT-groups with a maximum SCC $>200,000 \mathrm{cell} / \mathrm{mL}$ (Figure 4).

\section{Prevalence of Infection Postcalving}

The quarter-level prevalence of any IMI postcalving was lower in the CMT-group than in the SCC-group [119/3,243 (0.037, 95\% CI: $0.030-0.044)$ vs. $173 / 3,265$ (0.054, 95\% CI: $0.045-0.062), P=0.003]$ and the odds ratio that a quarter had an any IMI post calving was 1.53 (95\% CI: 0.11-0.99) for the SCC-group compared with the CMT-group (Table 10). Prevalence of IMI was lower among quarters not infected at drying off compared with those infected with a minor pathogen at drying off, which in turn was lower than those infected with a major pathogen at drying off $[0.037$ (95\% CI: $0.032-0.042$ ), 0.100 (95\% CI $0.075-0.125$ ), and 0.155 (0.097-0.213) for quarters from which no bacteria, a minor pathogen, or from which a major pathogen was isolated at drying off, respectively; $P<0.001]$. Fore quarters were less likely to have any IMI postcalving than rear quarters [0.033 (95\% CI: $0.027-0.039)$ vs.

Table 8. Odds ratio (OR) and SEM of bacteriological cure among quarters assigned to treatment at the end of lactation based on quarter-level California Mastitis Test (CMT) score or on cow maximum SCC

\begin{tabular}{llrrrrr}
\hline & & & & & \multicolumn{2}{c}{$95 \%$ CI } \\
\cline { 5 - 7 } $\begin{array}{l}\text { Reference } \\
\text { group }\end{array}$ & Category & OR & SEM & P-value & Low & High \\
\hline Allocation $^{1}$ & SCC group & 0.34 & 0.19 & 0.048 & 0.11 & 0.99 \\
IMI at dry off $^{2}$ & Major & 0.10 & 0.08 & 0.004 & 0.02 & 0.48 \\
Herd $^{3}$ & 2 & 0.24 & 0.24 & 0.147 & 0.04 & 1.65 \\
& 3 & 0.23 & 0.23 & 0.133 & 0.03 & 1.56 \\
& 4 & 1.51 & 1.48 & 0.672 & 0.22 & 10.34 \\
Intercept & & 499.69 & 866.32 & 0.000 & 16.71 & $14,943.03$ \\
\hline
\end{tabular}

${ }^{1}$ Reference category is CMT group.

${ }^{2}$ Reference category is isolation of a minor pathogen (i.e., coagulase-negative staphylococci, Corynebacterium spp., other) at drying off.

${ }^{3}$ Reference category is herd 1 . 
Table 9. Odds ratio (OR) and SEM for new IMI for quarters assigned to treatment at the end of lactation, based on quarter-level CMT score (CMT group) or on cow-maximum SCC (SCC group)

\begin{tabular}{|c|c|c|c|c|c|c|}
\hline \multirow[b]{2}{*}{ Reference group } & \multirow[b]{2}{*}{ Category } & \multirow[b]{2}{*}{ OR } & \multirow[b]{2}{*}{ SEM } & \multirow[b]{2}{*}{$P$-value } & \multicolumn{2}{|c|}{$95 \% \mathrm{CI}$} \\
\hline & & & & & Low & High \\
\hline Allocation $^{1}$ & SCC group & 1.43 & 0.21 & 0.016 & 1.07 & 1.92 \\
\hline \multirow[t]{3}{*}{ Herd $^{2}$} & 2 & 2.19 & 0.68 & 0.011 & 1.20 & 4.01 \\
\hline & 3 & 2.37 & 0.73 & 0.005 & 1.30 & 4.34 \\
\hline & 4 & 1.14 & 0.37 & 0.691 & 0.60 & 2.17 \\
\hline Quarter position ${ }^{3}$ & Rear & 1.92 & 0.27 & 0.000 & 1.46 & 2.53 \\
\hline \multirow[t]{2}{*}{ Lactation no. ${ }^{4}$} & 2 & 1.10 & 0.31 & 0.727 & 0.64 & 1.90 \\
\hline & 3 & 2.32 & 0.49 & 0.000 & 1.53 & 3.51 \\
\hline Intercept & & 0.00 & 0.00 & 0.000 & 0.00 & 0.01 \\
\hline
\end{tabular}

${ }^{1}$ Reference category is CMT group.

${ }^{2}$ Reference category is herd 1 .

${ }^{3}$ Reference category is a fore quarter.

${ }^{4}$ Reference category is first lactation.

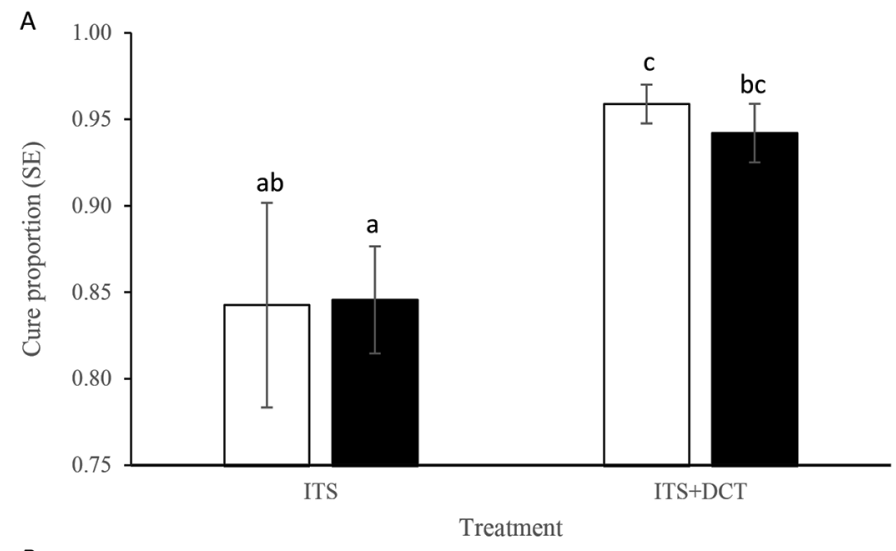

B

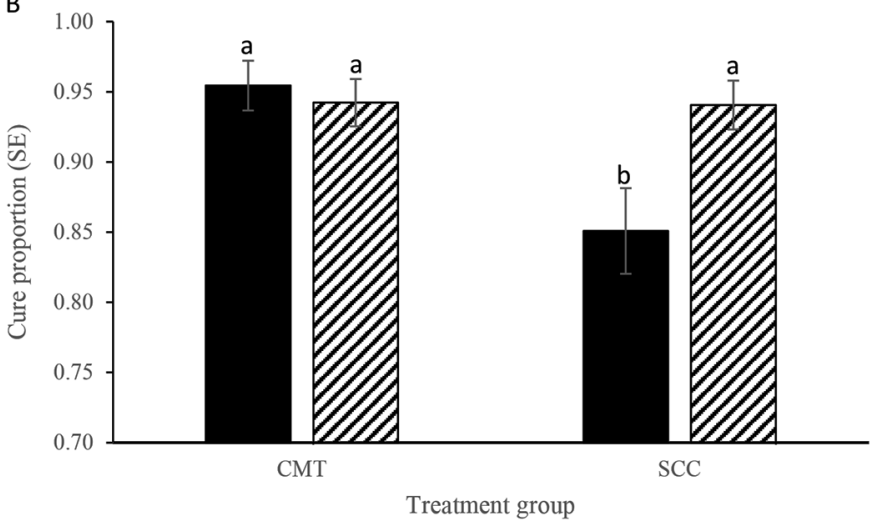

Figure 3. Estimated marginal mean cure proportion of all pathogens (SEM) for quarters treated with internal teat sealant (ITS) alone or with dry cow therapy (DCT) + ITS, categorized by (A) diagnosis method [open bar = allocation based on quarter-level California Mastitis Test $(\mathrm{CMT})$ score, solid bar = allocation at cow level based on SCC], and (B) maximum SCC $(\leq 200,000$ cells $/ \mathrm{mL}=$ solid bar, and $>200,000$ cells $/ \mathrm{mL}=$ hatched bar) and treatment allocation group (not actual treatment). Bars with different lowercase letters within panels differ at $P<0.05$.
0.057 (95\% CI: 0.049-0.065), $P<0.001]$. First and second lactation animals had a lower IMI prevalence of any IMI postcalving than third or greater lactation cows [0.028 (95\% CI: 0.019-0.037), 0.031 (95\% CI: 0.021-0.042), and 0.056 (0.048-0.064) for first, second, and third and subsequent lactations, respectively; $P$ $<0.001]$. Prevalence of any IMI post calving varied among herds $(P<0.001)$. There were no interactions between treatment group and herd, lactation number, or quarter position.

Quarters of cows in the CMT-group which had a maximum SCC $\leq 200,000$ cells $/ \mathrm{mL}$ had a lower prevalence of IMI than cows in the SCC-group with a maximum SCC $\leq 200,000$, and to CMT-group cows with a maximum $\mathrm{SCC}>200,000$ cell $/ \mathrm{mL}$, with quarters of cows allocated to DCT plus ITS, based on SCC not different from the other groups (Figure 5).

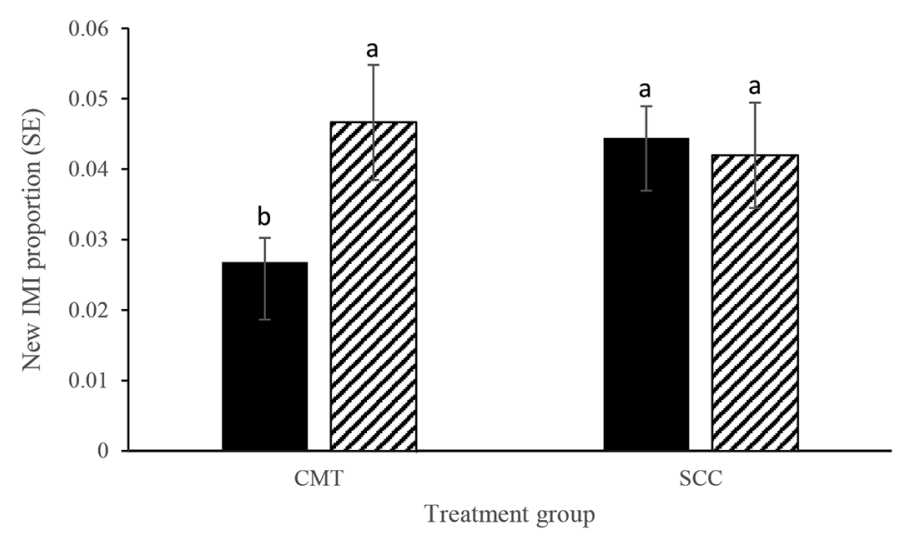

Figure 4. Estimated marginal mean new IMI proportion (SEM) for quarters treated with internal teat sealant (ITS) alone or with dry cow therapy + ITS, categorized by maximum SCC $(\leq 200,000$ cells/ $\mathrm{mL}=$ solid bar, and $>200,000$ cells $/ \mathrm{mL}=$ hatched bar) and treatment allocation group. Bars with different lowercase letters differ at $P<0.05$. 
Table 10. Odds ratio (OR) and SEM for IMI postcalving for quarters assigned to treatment at the end of lactation based on quarter-level California Mastitis Test (CMT) score or cow maximum SCC

\begin{tabular}{|c|c|c|c|c|c|c|}
\hline \multirow[b]{2}{*}{ Reference group } & \multirow[b]{2}{*}{ Category } & \multirow[b]{2}{*}{ OR } & \multirow[b]{2}{*}{ SEM } & \multirow[b]{2}{*}{$P$-value } & \multicolumn{2}{|c|}{$95 \%$ CI } \\
\hline & & & & & Low & High \\
\hline Allocation $^{1}$ & SCC group & 1.53 & 0.22 & 0.003 & 1.15 & 2.04 \\
\hline \multirow[t]{3}{*}{ Herd $^{2}$} & 2 & 2.37 & 0.70 & 0.004 & 1.33 & 4.23 \\
\hline & 3 & 2.52 & 0.74 & 0.002 & 1.41 & 4.49 \\
\hline & 4 & 1.08 & 0.34 & 0.801 & 0.59 & 2.00 \\
\hline \multirow[t]{2}{*}{ IMI at dry off ${ }^{3}$} & Minor & 3.26 & 0.59 & 0.000 & 2.28 & 4.65 \\
\hline & Major & 5.91 & 1.68 & 0.000 & 3.39 & 10.31 \\
\hline Quarter position $^{4}$ & Rear & 1.89 & 0.25 & 0.000 & 1.46 & 2.45 \\
\hline \multirow[t]{2}{*}{ Lactation no. ${ }^{5}$} & 2 & 1.11 & 0.30 & 0.687 & 0.66 & 1.87 \\
\hline & 3 & 2.18 & 0.44 & 0.000 & 1.47 & 3.24 \\
\hline Intercept & & 0.00 & 0.00 & 0.000 & 0.00 & 0.01 \\
\hline
\end{tabular}

${ }^{1}$ Reference category is CMT group.

${ }^{2}$ Reference category is herd 1 .

${ }^{3}$ Reference category is cows with no bacterial growth in any quarter at drying off. Note: cows classified as having a minor pathogen at drying off had one or more quarters infected with Corynebacterium species or coagulase-negative staphylococci, whereas cows categorized as having major pathogen infection had one or more quarters infected with Staphylococcus aureus, Streptococcus uberis, or Streptococcus dysgalactiae at drying off.

${ }^{4}$ Reference category is a fore quarter.

${ }^{5}$ Reference category is first lactation.

\section{Clinical Mastitis over the Dry Period}

Over the dry period there were $3 / 881(0.34 \%)$ versus $8 / 888(0.91 \%)$ cows diagnosed with clinical mastitis in the CMT-group versus SCC-group, respectively $(P=$ $0.13)$. A total of 3 and 11 quarters were diagnosed with clinical mastitis over the dry period in the CMT-group versus the SCC-group, respectively. Among the CMTgroup, 2 of the 3 affected quarters had an elevated CMT at dry-off and hence had been treated with DCT. Among the SCC-group, all cows with clinical mastitis over the dry period had a SCC $\leq 200,000$ cells $/ \mathrm{mL}$

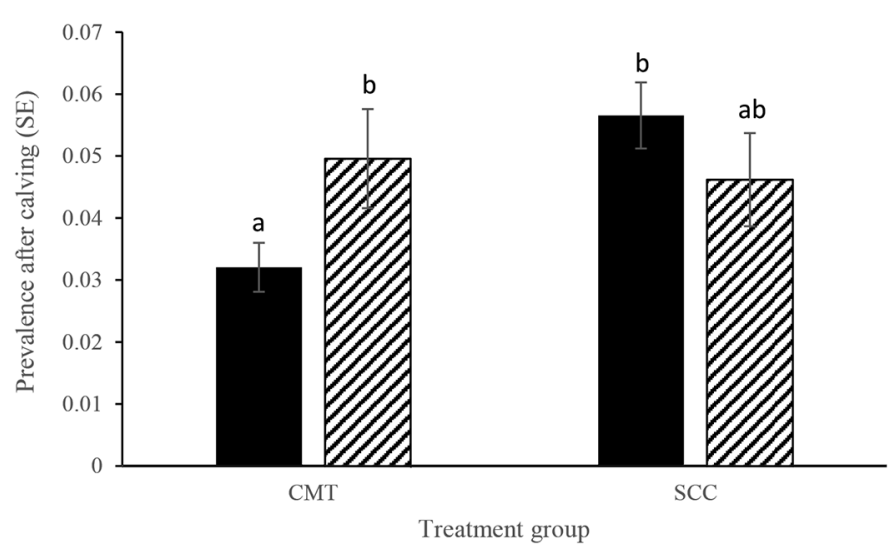

Figure 5. Estimated marginal mean (SEM) of prevalence of IMI after calving for quarters treated with internal teat sealant (ITS) alone or with dry cow therapy + ITS, categorized by maximum SCC $(\leq 200,000$ cells $/ \mathrm{mL}=$ solid bar, and $>200,000$ cells $/ \mathrm{mL}=$ hatched bar) and treatment allocation group. Bars with different lowercase letters differ at $P<0.05$. throughout lactation and had been treated with ITSalone.

Milk samples were collected from 8 quarters diagnosed with clinical mastitis over the dry period and isolates included Strep. uberis $(\mathrm{n}=6)$, Bacillus spp. (n $=1)$, and no growth $(\mathrm{n}=1)$. One each of the Strep. uberis and the Bacillus spp. infections had been isolated from the same quarter at the time of drying off, whereas the remaining 6 clinical mastitis events were due to a new IMI.

\section{Clinical Mastitis Postcalving}

There was a tendency for fewer of the CMT-group cows to be diagnosed with clinical mastitis in the first $30 \mathrm{~d}$ post calving compared with cows in the SCC-group [36/810 (4.4\%; $95 \%$ CI: $2.6-6.2)$ vs. $53 / 822$ (6.4\%; $95 \%$ CI: 3.9-8.6) for cows diagnosed with clinical mastitis in the CMT-group vs. SCC-group, respectively; $P=0.08$ ]. The difference in incidence of clinical mastitis between groups was $-1.9 \%(95 \% \mathrm{CI}:-4.1-0.3)$, hence as the upper $95 \%$ CI for the difference was not greater than $4 \%$ (the a priori defined acceptable difference), the clinical incidence in the CMT-group was noninferior to that of the SCC-group. The intraclass correlation $($ ICC) was $0.02(\mathrm{SEM}=0.05)$ and the likelihood ratio test was not significant $(P=0.28)$, demonstrating that there was a low level of clustering of clinical mastitis incidence within herd.

Using survival analysis, there was no difference in the hazard of clinical mastitis between the SCC and CMT-group at the bivariate (Kaplan-Meier) level $(P=$ 
Table 11. The hazard ratio (HR) and SEM for the risk of a cow being diagnosed with clinical mastitis in the first $30 \mathrm{~d}$ after calving from the final Cox's proportional hazard model, for cows where quarters were assigned to treatment at the end of the previous lactation based on California Mastitis Test (CMT) score at quarter level or cow maximum SCC at cow level

\begin{tabular}{lllcccc}
\hline & & & & & \multicolumn{2}{c}{$95 \%$ CI } \\
\cline { 5 - 7 } Reference group & Category & HR & SEM & $P$-value & Low & Hi \\
\hline Allocation $^{1}$ & SCC group & 1.30 & 0.29 & 0.25 & 0.83 & 2.02 \\
Lactation number $^{2}$ & 2 & 1.10 & 0.50 & 0.83 & 0.45 & 2.66 \\
Bacteria at dry off $^{3}$ & $>2$ & 2.14 & 0.71 & 0.02 & 1.12 & 4.10 \\
& Minor & 1.01 & 0.28 & 0.98 & 0.59 & 1.73 \\
& Major & 2.42 & 0.77 & 0.01 & 1.31 & 4.50 \\
\hline
\end{tabular}

${ }^{1}$ Reference category is CMT group.

${ }^{2}$ Reference category is first-lactation cows.

${ }^{3}$ Reference category is cows with no bacterial growth in any quarter at drying off. Note: cows classified as having a minor pathogen at drying off had one or more quarters infected with Corynebacterium species or coagulase-negative staphylococci, whereas cows categorized as having major pathogen infection had one or more quarters infected with Staphylococcus aureus, Streptococcus uberis, or Streptococcus dysgalactiae at drying off.

0.21; Figure 6). In the final Cox's proportional hazards model, the hazard of clinical mastitis in the first $30 \mathrm{~d}$ postpartum did not differ between cows in the CMTgroup versus those in the SCC-group $(P=0.25$; Table 11). The hazard of clinical mastitis was greater in older than younger cows, and in those cows with one or more quarters infected with a major pathogen at the time of drying off compared with those without a major pathogen IMI (Table 11).

At quarter level, presence of an IMI post calving increased the risk of diagnosis of clinical mastitis within $30 \mathrm{~d}$ of calving [62/293 (21.1\%) vs. 45/6,226 (0.7\%); OR

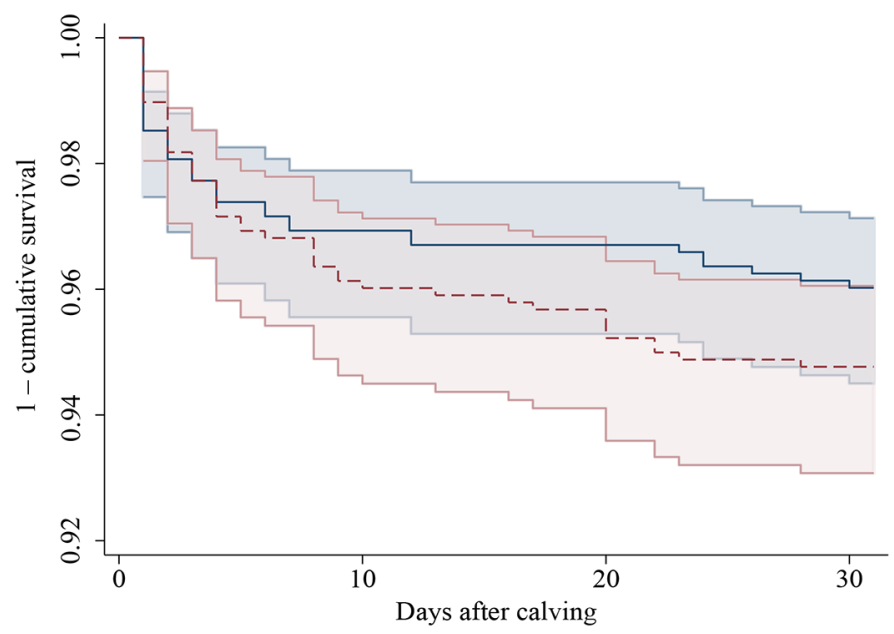

Figure 6. Graph showing 1 - cumulative survival (confidence bands) from a Kaplan-Meier survival analysis for cows for clinical mastitis in the first $30 \mathrm{~d}$ of lactation following treatment at drying off, assigned based on California Mastitis Test (CMT) score or maximum SCC at production recording. Cows assigned to dry off treatment based on CMT are represented by the solid line, and those assigned treatment based on SCC are represented by the dashed line.
$=64.4$ (95\% CI: 33.0-125.7), $P<0.001]$. Rear-quarters were more likely to be diagnosed with clinical mastitis than fore-quarters $[\mathrm{OR}=2.9$ (95\% CI: $1.6-5.0), P<$ $0.001]$, and incidence varied among herds $(P<0.001)$.

Milk samples were collected from 46 postpartum clinical mastitis cases. Of these, 41.3, 32.6, 13.0, and 6.5\% isolated no pathogen, Strep. uberis, Staph. aureus, and E. coli, respectively. The remaining isolates included one each of CNS, Trueperella spp., and a mixed major pathogen growth. There was no difference in distribution of bacterial species by treatment group $(P=0.33)$.

\section{SCC at First Postpartum Production Recording}

The first postpartum production recording occurred at $27.9(\mathrm{SD}=14.4)$ DIM. There was a treatment group by previous lactation maximum SCC interaction $(P=$ $0.005)$ whereby cows in the CMT-group with a maximum SCC $\leq 200,000$ cells $/ \mathrm{mL}$ had a lower SCC in the subsequent lactation than those animals with an SCC $\leq 200,000$ cells $/ \mathrm{mL}$ assigned to the SCC-group (Figure $7 \mathrm{a})$. There was also a treatment group by lactation number interaction for SCC $(P=0.03$; Figure $7 \mathrm{~b})$, as cows in the CMT-group that were in greater than the second lactation had a lower SCC than cows in the SCC-group in the same lactation group. SCC varied among herds $(P<0.001)$, varied by week in milk at the time of testing $(P<0.001)$, and was different $(P$ $<0.001$ ) between cows not infected drying off, infected only with minor pathogen, or infected with a major pathogen [31.3 (95\% CI: 29.1-33.7), 40.0 (95\% CI $35.6-45.0)$, and $59.9(47.7-75.1)$ geometric mean SCC $\times 1,000$ cells $/ \mathrm{mL}$ for cows with no infected glands, cows infected only with minor pathogens, or infected in one or more quarters with a major pathogen at drying off, respectively]. 
Table 12. Mass of antimicrobials (mg) used in total in cows assigned to dry-off treatment based on California Mastitis Test (CMT) score at quarter level or SCC at cow level, at the time of dry off (dry cow therapy antibiotic, DCT), or for clinical mastitis treatments either during the dry period (Dry) or in the first $30 \mathrm{~d}$ of the subsequent lactation (Lactation) and the average mass of antimicrobials used (mg/kg liveweight) assuming an average cow weight of $459 \mathrm{~kg}$

\begin{tabular}{|c|c|c|c|c|c|c|}
\hline Group & $\begin{array}{l}\text { DCT antibiotic } \\
(\mathrm{mg})\end{array}$ & \multicolumn{2}{|c|}{ Clinical mastitis treatments $(\mathrm{mg})$} & Total (mg) & No. cows & Average $\mathrm{mg} / \mathrm{kg}$ \\
\hline CMT & $1,112,000$ & 7,950 & 287,700 & $1,407,650$ & 884 & 3.47 \\
\hline
\end{tabular}

Fewer cows in the CMT-group had SCC > 200,000 cells $/ \mathrm{mL}$ at the first production recording in the subsequent lactation compared with the SCC-group $[8.3 \%$ (95\% CI: $6.4-10.2)$ vs. $11.4 \%$ (95\% CI: 9.1-13.6), respectively; $P=0.04)$. However, there tended to be a treatment group by maximum SCC in preceding lac-
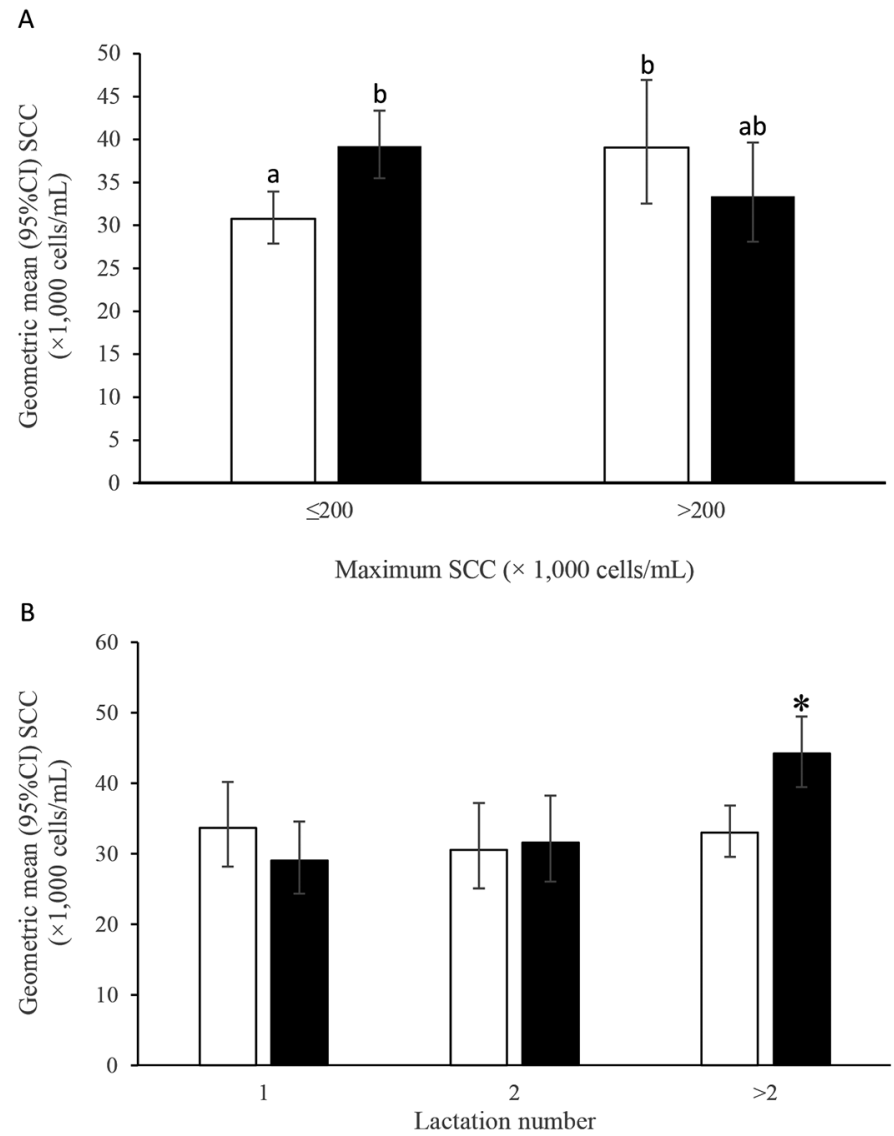

Figure 7. Geometric mean $(95 \% \mathrm{CI})$ of SCC $(\times 1,000$ cells $/ \mathrm{mL})$ at first postpartum production recording following treatment at drying off for cows allocated to treatment on the basis of California Mastitis Test (CMT) or maximum SCC by (A) maximum SCC in the preceding lactation and (B) lactation number. Cows allocated to dry-off treatment based on CMT are represented by the open bars, whereas those allocated based on SCC are represented by the solid bars. Columns with different lowercase letters in $(\mathrm{A})$ differ at $P<0.05$, and asterisks indicate significant difference between groups within lactation number in (B). tation interaction whereby cows with a previous SCC $\leq 200,000$ cells $/ \mathrm{mL}$ and allocated to the CMT-group had a lower proportion of cows with a SCC $>200,000$ cells $/ \mathrm{mL}$ at the first postpartum production recording, compared with cows allocated to the CMT-group with a SCC $>200,000$ cells $/ \mathrm{mL}$ in the previous lactation, and to cows in the SCC-group $(P=0.11$; Figure 8$)$. The proportion of cows with SCC $>200,000 / \mathrm{mL}$ increased with lactation number $(P<0.001)$ and declined with week postpartum at the first production recording $(P$ $<0.001)$.

\section{Antimicrobial Usage}

At drying off, $2,089 / 3,270(63.9 \%)$ and $883 / 3,311$ $(26.7 \%)$ of quarters were treated with DCT in the CMT- and SCC-groups, respectively.

The total mass of antimicrobials used was $63 \%$ higher in the CMT-group than in the SCC-group (3.47 vs. 2.12 $\mathrm{mg} / \mathrm{kg}$ liveweight; Table 12). Although the antimicrobial usage in the CMT-group was lower both in the dry period and the first $30 \mathrm{~d}$ of subsequent lactation, the

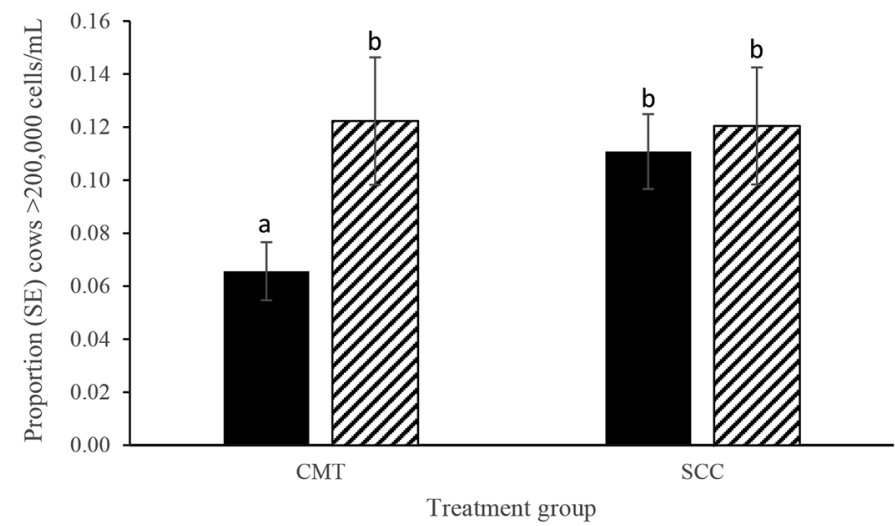

Figure 8. Estimated marginal mean proportion (SEM) of cows with SCC >200,000 cells $/ \mathrm{mL}$ at first postpartum production recording categorized by maximum SCC in the previous lactation $(\leq 200,000$ cells $/ \mathrm{mL}=$ solid bar, and $>200,000$ cells $/ \mathrm{mL}=$ hatched bar $)$ and treatment allocation group. Bars with different lowercase letters differ at $P<0.05$. 
mass of antimicrobials used at drying off was 2.3 times higher in this group than in the SCC-group (Table 12).

Among cows with a maximum SCC $>200,000$ cells/ $\mathrm{mL}$ and allocated to the CMT-group, $52 \%$ of animals were CMT-positive in all quarters and hence treated in all 4 quarters with DCT and a total of 224/892 (25.1\%) of quarters were CMT test-negative (i.e., CMT score = 0 ) and hence treated with ITS-alone.

\section{DISCUSSION}

We assessed the effect of selecting and treating at quarter-level with DCT based on CMT compared, with selecting and treating cows for DCT based on maximum SCC across lactation. Selection at quarterlevel based on CMT resulted in more quarters being infused with DCT compared with selecting cows based on SCC. Selection based on CMT resulted in a higher bacteriological cure proportion, a lower new IMI proportion over the dry period, a lower prevalence of IMI postcalving, and a lower proportion of cows with an SCC >200,000 cells/mL at first production recording in the subsequent lactation, but there was no difference in the clinical mastitis incidence over the dry period or the first $30 \mathrm{~d}$ of subsequent lactation. However, overall antimicrobial usage was higher in the cows where treatment was based on CMT score compared with cows selected on SCC.

A priori it had been assumed that approximately $10 \%$ of cows would be diagnosed with clinical mastitis in the first $30 \mathrm{~d}$ of subsequent lactation. This assumption was used as the basis of the power analysis, and it was calculated at approximately 1,400 cows in total would be required for the final analysis on this basis. It had also originally been assumed that the ICC would be about $10 \%$. In the final model, the ICC was $2 \%$ and the likelihood ratio test comparing the hierarchical (random effects) model with a logistic regression model (i.e., model not considering the clustered nature of the data) was not significant suggesting that clustering was not important for this outcome variable. This may be due to the low prevalence of contagious IMI, which are associated with a higher ICC (Barkema et al., 1997). Hence as 1,578 cows were included in the final analysis, sufficient cases were enrolled to test the noninferiority hypothesis that allocation of cows based on CMT was noninferior to allocation based on SCC in terms of clinical mastitis outcome in the first $30 \mathrm{~d}$ of the subsequent lactation. The 4 herds enrolled in our study ranged in size from approximately 230 to 700 cows, comparable with the national average herd size, approximately 450 animals. Additionally, the clinical mastitis incidence rate ranged from 10 to $19 \%$ broadly in line with previously reported incidence of $13 \%$ (McDougall et al., 2007). Hence these herds are broadly representative of spring calving, pasture-based dairy herds in New Zealand and the results and inferences drawn from the current study are likely to be externally valid for the industry.

\section{Diagnosis of IMI}

The CMT is a semiquantitative test and may be subject to variation among operators (Leach et al., 2008). We aimed to minimize the effect of operator by using a single senior technician to undertake the CMT for each herd. Additionally, as all cows irrespective of allocation treatment group were subjected to CMT and as the technician was blinded to treatment group allocation, it is not believed that bias in diagnosis and hence allocation is likely to have occurred.

A CMT cutpoint of $>0$ resulted in a $96 \%$ Se, but only a $38 \% \mathrm{Sp}$, in agreement with previous studies (Poutrel and Rainard, 1981; Sanford et al., 2006; Bhutto et al., 2012). Hence most major pathogen IMI were detected at this cutpoint, but the PPV was only $3.4 \%$ indicating that over $96 \%$ of quarters with a positive CMT score did not have a major pathogen IMI. This high proportion of false positive diagnoses resulted in $63 \%$ of all quarters allocated to the CMT-group being treated with DCT. If we had used a CMT cut-point $\geq 1$ then only $19 \%$ of quarters would have been treated with DCT. However, a CMT cut-point of $\geq 1$ resulted in nearly a $20 \%$ drop in Se with an associated increase in false-negative results. As we did not have a treatment allocation group based on this higher CMT cut-point, we are unable to determine the effect of using this cutpoint on cure proportion, new IMI, postcalving IMI prevalence, or clinical mastitis outcomes. We chose a cut-point of $\geq$ trace for the current study to maximize the sensitivity of the CMT diagnosis, and to increase the chance that herd owners would be willing to participate in the study. A recently published study assessed selection of cows for DCT based on DHI SCC compared with selection based on CMT cut-points of $\geq 1$ or $\geq 2$ and they found that 31 and $12 \%$ of quarters were CMT test positive, respectively. They found no difference in prevalence of major pathogen IMI after calving among groups, but a lower prevalence of minor pathogen IMI, a lower SCC at the first DHI test recording in the subsequent lactation where a cutpoint $\geq 1$ was used relative to the teatseal alone control group in previously low SCC cows (Swinkels et al., 2021). This indicates that there is likely a trade-off between CMT cutpoint and subsequent prevalence of intramammary infection, SCC and incidence risk of clinical mastitis. Longer term 
studies are required to assess the effect of CMT cutpoint decisions on subsequent milk quality and animal welfare using different CMT and SCC cutpoints.

From a practical perspective undertaking CMT of large numbers of animals at the seasonal dry off which occurs in New Zealand may appear challenging. However, many veterinary businesses in New Zealand already employ trained technicians who are undertaking dry off procedures in many herds and addition of a CMT step to that dry off process is feasible.

The AUC for the ROC was similar for selection of cows based on cow-level SCC and selection at quarterlevel using the CMT. However, as the CMT uses only 5 categories (i.e., 0 , trace, $1,2,3$ ) the precision of categorization is less than for $\mathrm{SCC}$ which is a continuous variable. A SCC cutpoint of $>200,000$ cells $/ \mathrm{mL}$ resulted in a Se and Sp that were both $>75 \%$, similar to previous reports (McDermott et al., 1982; Dohoo and Leslie, 1991; Reksen et al., 2008; McDougall et al., 2021). The effect of the high Se but lower Sp of CMT relative to SCC, resulted in a higher proportion of quarters being treated with DCT in the CMT-group compared with the SCC-group.

Use of the SCC cut-point of $>200,000$ cells/ML in the current study resulted in some false negative diagnoses. A total of 134/2412 (5.6\%) and 13/2412 (0.5\%) of the quarters allocated to the ITS-alone treatment in the SCC-group had a minor, or a major IMI, respectively. The current New Zealand recommendations are that a cut-point of any DHI recording of $>150,000$ cells $/ \mathrm{mL}$ be used to define likely presence of IMI. We chose to increase this to $>200,000$ cells $/ \mathrm{mL}$ to align with international only accepted cut-points, with the aim of reducing overall antimicrobial usage in the New Zealand dairy industry. The effect of using different cut-points on the proportion of animals treated and on bacteriological cure and new IMI rate were beyond the scope of the study, but require further exploration.

\section{Bacteriological Cure Proportion}

Overall, bacteriological cure proportion was higher in the CMT than the SCC-group. This was associated with a higher proportion of quarters with an IMI being treated with DCT in the CMT-group. By design, cows with an SCC $\leq 200,000$ cells $/ \mathrm{mL}$ were not treated with DCT in the SCC-group, irrespective of whether an IMI was present or not. This resulted in some quarters with either minor or major pathogen IMI not receiving DCT. The bacteriological cure proportion among infected quarters that were treated with DCT and ITS was $13 \%$ higher than infected quarters treated with ITS-alone. Of note is that the cure rate of quarters with an IMI treated with ITS-alone was greater than $85 \%$, suggesting that in low SCC cows the great majority of IMI present at the end of lactation may self-cure or be in some way be affected by the bismuth subnitrate in ITS. A meta-analysis of DCT found that the bacteriological cure rate following DCT averaged $78 \%$ compared with a cure rate of $46 \%$ in untreated quarters (Halasa et al., 2009a). However, in that meta-analysis the comparison was between DCT and no treatment at all. In cows with an SCC $\leq 200,000$ cells/mL, the apparent overall cure rate was 72 and $78 \%$, respectively, in cows infused with ITS-alone compared with cows treated with a combination of DCT and ITS (Bradley et al., 2010). Taken together these data suggest that ITS-alone is appropriate for low SCC cows even where an IMI may be present. Apparent failure to cure may be due to a true failure to cure bacteria associated with an IMI at drying off or may be due to cure followed by reinfection with the same bacterial species. The sampling regimens and laboratory techniques commonly used in DCT studies fail to differentiate these 2 possibilities. Hence one explanation for the higher apparent cure rate observed in the current study, and others where ITS-alone is used, may be that the ITS was associated with spontaneous bacteriological cure, and a reduced probability of reinfection with the same bacterial species. A recent in vitro study suggests that bismuth subnitrate may have antimicrobial activity (Notcovich et al., 2020).

\section{New Infection Rate over the Nonlactation Period}

Overall, quarters assigned to the CMT-group had a lower new IMI proportion over the dry period than those assigned to the SCC-group. This difference occurred as cows with a maximum SCC $\leq 200,000$ cell/ $\mathrm{mL}$ in the CMT-group had a lower new IMI proportion than cows with a similar SCC in the SCC-group. No difference in new IMI proportion was found following infusion of an ITS-alone compared with infusion of a combination of DCT and ITS in quarters without an IMI at dry off (Woolford et al., 1998). Similarly, a UK study which assigned cows with a SCC $<200,000$ cells/ $\mathrm{mL}$ to be treated in all 4 quarters with ITS-alone, or with a combination of an antimicrobial and an ITS found no difference in the new IMI rate across the dry period between these treatment groups (Bradley et al., 2010). As those studies used proportionally more antimicrobial than in the current study it may have been expected that our study would have had less power to demonstrate differences in new IMI proportion. In our study, a proportion of previously low SCC cows in the CMT-group were treated with DCT and ITS based on a positive CMT test whereas all quarters of low 
SCC cows in the SCC-group were treated with ITSalone. Numerically, quarters in the CMT-group that were CMT positive (i.e., $\geq$ trace) and treated with a combination of DCT and ITS had a lower new IMI proportion than CMT-group cows with a CMT score of zero, and treated with ITS-alone, or the SCC-group cows, irrespective of CMT score, and treated with ITSalone. This suggests that the combination of DCT and ITS reduced the risk of new IMI over the dry period in these low SCC cows, which also had elevation of quarter-level SCC as indicated by an elevated CMT score. Alternatively, as the Se of microbiology is less than $100 \%$ (Dohoo et al., 2011), there were likely false negative IMI diagnoses at drying off and hence the possibility of isolation of the same bacteria after calving. It is possible that addition of DCT resulted in higher bacteriological cure rate of these undiagnosed IMI at drying off, resulting in a lower likelihood of isolation of bacteria post calving and hence a lower apparent new IMI proportion.

\section{Postcalving Prevalence of IMI, and Clinical and Subclinical Mastitis}

The CMT-group had a lower prevalence of IMI postcalving. A combination of a higher bacteriological cure, and a lower new IMI proportion in the CMT-group than the SCC-group resulted in this difference in post calving IMI prevalence. A meta-analysis of studies comparing blanket with selective DCT demonstrated that the prevalence of IMI postcalving was lower where DCT was used relative to controls [relative risk (RR) $=1.34$ (95\% CI: 1.13-1.159); Winder et al., 2019]. However, when the data were stratified as to whether the control group animals were left untreated or were treated with ITS-alone, there was no difference in the prevalence of IMI at calving between cows treated with ITS-alone compared with DCT $[\mathrm{RR}=1.09$ (95\% CI: 0.92-1.28)]. That analysis did not include studies where ITS-alone was compared with ITS and DCT. In a UK study, cows with a maximum SCC $<200,000$ cells $/ \mathrm{mL}$ and assigned to treatment with ITS-alone or DCT and ITS did not differ in the postcalving prevalence of IMI (Bradley et al., 2010). These studies illustrate the importance of not simply discontinuing DCT usage, but rather reducing the risk of new IMI over the dry period by use of ITS.

At quarter level, presence of an IMI at calving was associated with a higher clinical mastitis incidence rate in the first $30 \mathrm{~d}$ after calving. However, at cow level, despite the difference in prevalence between treatment groups postcalving, there was no difference in clinical mastitis incidence rate over the first $30 \mathrm{~d}$ of lactation.
The reduction in power associated with using cow level rather than quarter level analysis in this case may be an explanation for this apparent contradiction.

Among all cows with an SCC $\leq 200,000$ cells $/ \mathrm{mL}$ in the preceding lactation, cows in the CMT-group had a lower SCC and were less likely to have an SCC >200,000 cells/mL in the subsequent lactation than the SCCgroup cows. In contrast, SCC did not differ between groups in the subsequent lactation where the SCC was $>200,000$ cells $/ \mathrm{mL}$ in the preceding lactation. Again, this is likely associated with the higher prevalence of IMI after calving in the SCC-group where IMI present at drying off were not treated with DCT, resulting in a higher likelihood of IMI after calving.

\section{Antimicrobial Usage}

Dry cow therapy use was approximately 2.5 times higher in the CMT- than SCC-group. Although the CMT-group had lower antimicrobial usage associated with clinical mastitis both in the dry and early lactation periods, the total mass of antimicrobials used in the CMT-group was still higher overall than for the SCC-group. We did not have a group of cows that were treated with DCT and ITS in every quarter irrespective of IMI status at drying off, which would have resulted in $100 \%$ of cows being treated with DCT. So, although use of CMT as a basis of treatment of quarters with DCT resulted in higher DCT usage than selection based on SCC, it did result in a lower DCT usage compared with when every quarter of every cow was treated with DCT. In the current study, selection based on CMT resulted in $37 \%$ less and the SCC-based selection resulted in approximately $78 \%$ less DCT usage compared with every quarter of every cow being treated with DCT. Thus, for herds for which production recording SCC data are not available, use of the CMT as a basis to select quarters for DCT does reduce DCT usage.

Further work is required to determine if the greater Se, but lower Sp, and PPV afforded by quarter level selection based on CMT, and its associated higher cure proportions, lower new IMI proportions and lower post calving IMI prevalence is cost-effective and does not increase the risk of emergence of antimicrobial resistance, compared with SCC-based selection. Not using DCT in a proportion of truly infected quarters in the SCCgroup which had a maximum SCC $\leq 200,000$ cells/mL did have effects on economically important outcomes, including increased risk of subclinical and clinical mastitis in the subsequent lactation. The consequences of an DCT selection policy of using SCC alone in terms of prevalence of subclinical mastitis and clinical mastitis over multiple years remains to be determined. Model- 
ing from the Netherlands suggested that the transition from whole herd to selective DCT might be associated with increased risk of clinical and subclinical mastitis, but this was dependent on the cut-points used to assign cows to DCT treatment and cows below the cutpoints were left untreated and not infused with ITS (Scherpenzeel et al., 2016). In the same analysis, the selective DCT scenario with the optimal economic outcome was associated with an increased incidence of clinical mastitis and of subclinical mastitis relative to blanket DCT (Scherpenzeel et al., 2016). This suggests that there is a trade-off between reducing antimicrobial usage and risk of subclinical and clinical mastitis, but that the economic optimum is not associated with minimizing the risk of subclinical and clinical mastitis. It could be hypothesized that the prevalence of subclinical mastitis may increase across time with selective DCT with potential increases in mastitis incidence and bulk milk SCC. However, data from the Netherlands where treatment of all cows at drying off with DCT is no longer practiced demonstrated that there were no substantive increases in mastitis incidence or SCC following introduction of restrictions on DCT usage (Santman-Berends et al., 2016; Vanhoudt et al., 2018). Modeling of mastitis control measures in the UK also demonstrated that use of selective DCT in low SCC cows was cost-effective, but that other factors such as hygiene of infusion, and cleanliness of the environment were important procedures in managing mastitis (Down et al., 2016). Thus, adoption of a selective DCT policy requires maintenance or improvement in other mastitis control measures to ensure that biologically and economically acceptable outcomes occur in conjunction with the reduced DCT usage.

Producers and veterinarians often express concern about misclassification of quarters in cows as uninfected based on SCC data. In our study, although there truly were both major and minor pathogen infected quarters in the ITS-alone groups, no cow died of clinical mastitis following infusion of ITS-alone into quarters that were infected. This suggests that, although bacteriological cure or new infection proportion, and hence prevalence postpartum, is higher in the ITSalone group, no animal welfare issues are created with this strategy. Additionally, there was no difference in incidence of clinical mastitis over the dry period or in the first $30 \mathrm{~d}$ of subsequent lactation in the ITS-alone low SCC-group compared with other groups of animals. It is also true that although use of the CMT resulted in more cows and quarters being treated with $\mathrm{DCT}$ in the cows with a low maximum SCC, misclassification also occurred in this group, as 26/2,432 (1.1\%) and $2 / 2,432(0.08 \%)$ of quarters that were CMT negative, had minor and major IMI, respectively. Again, by design, quarters that were CMT-negative did not receive antibiotic DCT, and there were no deleterious effects of infusion of ITS-alone into these quarters.

\section{CONCLUSIONS}

Selection of quarters for DCT treatment at the end of lactation based on a quarter level $\mathrm{CMT}>0$ results in greater overall antimicrobial usage compared with selection based on a maximum production recording SCC >200,000 cells $/ \mathrm{mL}$ and treatment allocation at cow level. Both approaches result in less antimicrobial usage than when all quarters of all cows are treated with DCT, irrespective of likely infection status. Quarters selected for DCT treatment based on CMT had a higher bacteriological cure proportion, a lower incidence of new IMI over the nonlactating period, and a lower prevalence of IMI following calving. There was no difference in clinical mastitis incidence over the nonlactating period and in the first $30 \mathrm{~d}$ of lactation among cows selected for DCT therapy, based on CMT compared with selection based on SCC. Hence, use of CMT to select quarters for DCT offers an effective approach for those herds for which production recording SCC data are not available.

\section{ACKNOWLEDGMENTS}

The collaboration of the herd owners and their staff, and the technical staff of Cognosco, Anexa (Morrinsville, New Zealand), including Elizabeth Blythe, Anna Maisey, Yvette MacPherson, and Cathy Yanez are gratefully acknowledged. This study was funded by the dairy farmers of New Zealand via DairyNZ Inc. and by the Sustainable Farming Fund of the Ministry for Primary Industries, New Zealand. Zoetis NZ Ltd. provided the products used in this study. The authors have not stated any conflicts of interest.

\section{REFERENCES}

Barkema, H. W., Y. H. Schukken, T. J. G. M. Lam, D. T. Galligan, M. L. Beiboer, and A. Brand. 1997. Estimation of interdependence among quarters of the bovine udder with subclinical mastitis and implications for analysis. J. Dairy Sci. 80:1592-1599. https://doi .org/10.3168/jds.S0022-0302(97)76089-2.

Bhutto, A. L., R. D. Murray, and Z. Woldehiwet. 2012. California mastitis test scores as indicators of subclinical intra-mammary infections at the end of lactation in dairy cows. Res. Vet. Sci. 92:13-17. https://doi.org/10.1016/j.rvsc.2010.10.006.

Bradley, A. J., J. E. Breen, B. Payne, and M. J. Green. 2011. A comparison of broad-spectrum and narrow-spectrum dry cow therapy used alone and in combination with a teat sealant. J. Dairy Sci. 94:692-704. https://doi.org/10.3168/jds.2010-3192.

Bradley, A. J., J. E. Breen, B. Payne, P. Williams, and M. J. Green. 2010. The use of a cephalonium containing dry cow therapy and an 
internal teat sealant, both alone and in combination. J. Dairy Sci. 93:1566-1577. https://doi.org/10.3168/jds.2009-2725.

Cameron, M., S. McKenna, K. MacDonald, I. Dohoo, J. Roy, and G. Keefe. 2014. Evaluation of selective dry cow treatment following on-farm culture: Risk of postcalving intramammary infection and clinical mastitis in the subsequent lactation. J. Dairy Sci. 97:270284. https://doi.org/10.3168/jds.2013-7060.

Collineau, L., C. Belloc, K. D. C. Stärk, A. Hémonic, M. Postma, J. Dewulf, and C. Chauvin. 2017. Guidance on the selection of appropriate indicators for quantification of antimicrobial usage in humans and animals. Zoonoses Public Health 64:165-184. https:/ /doi.org/10.1111/zph.12298

Compton, C., and S. McDougall. 2014. Patterns of antibiotic sales to Waikato dairy farms. Vetscript 27:22-24.

Dodd, F. H., D. R. Westgarth, F. K. Neave, and R. G. Kingwill. 1969. Mastitis - The strategy of control. J. Dairy Sci. 52:689-695. https: //doi.org/10.3168/jds.S0022-0302(69)86631-2.

Dohoo, I. R., and K. E. Leslie. 1991. Evaluation of changes in somatic cell counts as indicators of new intramammary infections. Prev. Vet. Med. 10:225-237. https://doi.org/10.1016/0167 $-5877(91) 90006-\mathrm{N}$.

Dohoo, I. R., J. Smith, S. Andersen, D. F. Kelton, and S. Godden. 2011. Diagnosing intramammary infections: Evaluation of definitions based on a single milk sample. J. Dairy Sci. 94:250-261. https://doi.org/10.3168/jds.2010-3559.

Down, P. M., A. J. Bradley, J. E. Breen, W. J. Browne, T. Kypraios, and M. J. Green. 2016. A Bayesian micro-simulation to evaluate the cost-effectiveness of interventions for mastitis control during the dry period in UK dairy herds. Prev. Vet. Med. 133:64-72. https://doi.org/10.1016/j.prevetmed.2016.09.012.

Dufour, S., V. Wellemans, J.-P. Roy, P. Lacasse, A. Ordonez-Iturriaga, and D. Francoz. 2019. Non-antimicrobial approaches at drying-off for treating and preventing intramammary infections in dairy cows. Part 1. Meta-analyses of efficacy of using an internal teat sealant without a concomitant antimicrobial treatment. Anim. Health Res. Rev. 20:86-97. https://doi.org/10.1017/S1466252319000070.

Godden, S., E. Royster, K. Patel, and J. Timmerman. 2016. Selective dry cow therapy: We can do this. Pages $8-15$ in Proc. NMC Regional Meeting. NMC.

Gohary, K., and S. McDougall. 2018. Predicting intramammary infection status at drying off using indirect testing of milk samples. N. Z. Vet. J. 66:312-318. https://doi.org/10.1080/00480169.2018 .1509741

Golder, H. M., A. Hodge, and I. J. Lean. 2016. Effects of antibiotic dry-cow therapy and internal teat sealant on milk somatic cell counts and clinical and subclinical mastitis in early lactation. J. Dairy Sci. 99:7370-7380. https://doi.org/10.3168/jds.2016-11114.

Halasa, T., M. Nielen, A. C. Whist, and O. Østerås. 2009a. Metaanalysis of dry cow management for dairy cattle. Part 2. Cure of existing intramammary infections. J. Dairy Sci. 92:3150-3157. https://doi.org/10.3168/jds.2008-1741.

Halasa, T., O. Osteras, H. Hogeveen, T. van Werven, and M. Nielen. 2009b. Meta-analysis of dry cow management for dairy cattle. Part 1. Protection against new intramammary infections. J. Dairy Sci. 92:3134-3149. https://doi.org/10.3168/jds.2008-1740.

Kabera, F., S. Dufour, G. Keefe, M. Cameron, and J.-P. Roy. 2020. Evaluation of quarter-based selective dry cow therapy using Petrifilm on-farm milk culture: A randomized controlled trial. J. Dairy Sci. 103:7276-7287. https://doi.org/10.3168/jds.2019-17438.

Leach, K. A., M. J. Green, J. E. Breen, J. N. Huxley, R. Macaulay, H. T. Newton, and A. J. Bradley. 2008. Use of domestic detergents in the California mastitis test for high somatic cell counts in milk. Vet. Rec. 163:566-570. https://doi.org/10.1136/vr.163.19.566.

McDermott, M. P., H. N. Erb, and R. P. Natzke. 1982. Predictability by somatic cell counts related to prevalence of intramammary infection within herds. J. Dairy Sci. 65:1535-1539. https://doi.org/ 10.3168/jds.S0022-0302(82)82378-3.

McDougall, S., D. G. Arthur, M. A. Bryan, J. J. Vermunt, and A. M. Weir. 2007. Clinical and bacteriological response to treatment of clinical mastitis with one of three intramammary antibiotics. N. Z. Vet. J. 55:161-170. https://doi.org/10.1080/00480169.2007.36762.
McDougall, S., J. Williamson, K. Gohary, and J. Lacy-Hulbert. 2021. Detecting intramammary infection at the end of lactation in dairy cows. J. Dairy Sci. 104:10232-10249.

Mein, G. A., F. Neijenhuis, W. F. Morgan, D. J. Reinemann, J. E. Hillerton, J. R. Baines, I. Ohnstad, M. D. Rasmussen, L. Timms, J. S. Britt, R. Farnsworth, N. Cook, and T. Hemlin. 2001. Evaluation of bovine teat conditions in commercial dairy herds 1 . Noninfectious factors. Pages 347-351 in Proc. 2nd Int. Symp. Mast. Milk Qual. NMC.

Middleton, J. R., L. K. Fox, G. Pighetti, and C. Petersson-Wolfe. 2017. Laboratory Handbook on Bovine Mastitis, 3rd ed. NMC.

Notcovich, S., N. B. Williamson, S. Flint, J. Yapura, Y. H. Schukken, and C. Heuer. 2020. Effect of bismuth subnitrate on in vitro growth of major mastitis pathogens. J. Dairy Sci. 103:7249-7259. https://doi.org/10.3168/jds.2019-17830.

Pantoja, J. C. F., C. Hulland, and P. Ruegg. 2009. Dynamics of somatic cell counts and intramammary infections across the dry period. Prev. Vet. Med. 90:43-54. https://doi.org/10.1016/j.prevetmed 2009.03.012.

Pol, M., and P. L. Ruegg. 2007. Treatment practices and quantifications of antimicrobial drug usage in conventional and organic dairy farms in Wisconsin. J. Dairy Sci. 90:249-261. https://doi.org/10 .3168/jds.S0022-0302(07)72626-7.

Poutrel, B., and P. Rainard. 1981. California Mastitis test guide of selective dry cow therapy. J. Dairy Sci. 64:241-248. https://doi .org/10.3168/jds.S0022-0302(81)82560-X.

Pyörälä, S. 2003. Indicators of inflammation in the diagnosis of mastitis. Vet. Res. 34:565-578. https://doi.org/10.1051/vetres:2003026.

Rabiee, A. R., and I. J. Lean. 2013. The effect of internal teat sealant products (Teatseal and Orbeseal) on intramammary infection, clinical mastitis, and somatic cell counts in lactating dairy cows: A meta-analysis. J. Dairy Sci. 96:6915-6931. https://doi.org/10 $.3168 /$ jds.2013-6544.

Reksen, O., L. Sølverød, and O. Østerås. 2008. Relationships between milk culture results and composite milk somatic cell counts in Norwegian dairy cattle. J. Dairy Sci. 91:3102-3113. https://doi.org/ 10.3168/jds.2008-1006

Rindsig, R. B., R. G. Rodewald, A. R. Smith, N. K. Thomsen, and S. L. Spahr. 1979. Mastitis history, California Mastitis Test, and somatic cell counts for identifying cows for treatment in a selective dry cow therapy program. J. Dairy Sci. 62:1335-1339. https://doi .org/10.3168/jds.S0022-0302(79)83421-9.

Rowe, S. M., S. M. Godden, D. V. Nydam, P. J. Gorden, A. Lago, A. K. Vasquez, E. Royster, J. Timmerman, and M. J. Thomas. 2020. Randomized controlled trial investigating the effect of 2 selective dry-cow therapy protocols on udder health and performance in the subsequent lactation. J. Dairy Sci. 103:6493-6503. https://doi .org/10.3168/jds.2019-17961.

Sanford, C. J., G. P. Keefe, J. Sanchez, R. T. Dingwell, H. W. Barkema, K. E. Leslie, and I. R. Dohoo. 2006. Test characteristics from latent-class models of the California Mastitis Test. Prev. Vet. Med. 77:96-108. https://doi.org/10.1016/j.prevetmed.2006.06.006.

Santman-Berends, I. M. G. A., J. M. Swinkels, T. J. G. M. Lam, J. Keurentjes, and G. van Schaik. 2016. Evaluation of udder health parameters and risk factors for clinical mastitis in Dutch dairy herds in the context of a restricted antimicrobial usage policy. J. Dairy Sci. 99:2930-2939. https://doi.org/10.3168/jds.2015-10398.

Sargeant, J. M., K. E. Leslie, B. Shirley, B. Pulkrabek, and G. H. Lim. 2001. Sensitivity and specificity of somatic cell count and California mastitis test for identifying intramammary infection in early lactation. J. Dairy Sci. 84:2018-2024. https://doi.org/10.3168/jds .S0022-0302(01) 74645-0.

Scherpenzeel, C. G. M., I. E. M. den Uijl, G. van Schaik, R. G. M. Olde Riekerink, H. Hogeveen, and T. J. G. M. Lam. 2016. Effect of different scenarios for selective dry-cow therapy on udder health antimicrobial usage, and economics. J. Dairy Sci. 99:3753-3764. https://doi.org/10.3168/jds.2015-9963.

Schukken, Y. H., J. A. H. Smit, F. J. Grommers, D. van der Geer, and A. Brand. 1989. Effect of freezing on bacteriologic culture of mastitis milk samples. J. Dairy Sci. 72:1900-1906. https://doi.org/ 10.3168/jds.S0022-0302(89)79309-7. 
Stevens, M., S. Piepers, K. Supre, J. Dewulf, and S. De Vliegher. 2016. Quantification of the antimicrobial consumption in adult cattle on dairy herds in Flanders, Belgium, and the association with udder health, milk quality and production performances. J. Dairy Sci. 99:2118-2130. https://doi.org/10.3168/jds.2015-10199.

Swinkels, J. M., K. A. Leach, J. E. Breen, B. Payne, V. White, M. J. Green, and A. J. Bradley. 2021. Randomized controlled field trial comparing quarter and cow level selective dry cow treatment using the California Mastitis Test. J. Dairy Sci. 104:9063-9081. https:// doi.org/10.3168/jds.2020-19258.

Timms, L. L., and L. H. Schultz. 1987. Dynamics and significance of coagulase-negative staphylococcal intramammary infections. J. Dairy Sci. 70:2648-2657. https://doi.org/10.3168/jds.S0022 $-0302(87) 80335-1$.

Vanhoudt, A., K. van Hees-Huijps, A. T. M. van Knegsel, O. C. Sampimon, J. C. M. Vernooij, M. Nielen, and T. van Werven. 2018. Effects of reduced intramammary antimicrobial use during the dry period on udder health in Dutch dairy herds. J. Dairy Sci. 101:3248-3260. https://doi.org/10.3168/jds.2017-13555.

Vasquez, A. K., D. V. Nydam, C. Foditsch, M. Wieland, R. Lynch, S. Eicker, and P. D. Virkler. 2018. Use of a culture-independent on-farm algorithm to guide the use of selective dry-cow antibiotic therapy. J. Dairy Sci. 101:5345-5361. https://doi.org/10.3168/jds .2017-13807.

Winder, C. B., J. M. Sargeant, D. F. Kelton, S. J. Leblanc, T. F. Duffield, J. Glanville, H. Wood, K. J. Churchill, J. Dunn, M. Bergevin, K. Dawkins, S. Meadows, and A. M. O'Connor. 2019. Comparative efficacy of blanket versus selective dry-cow therapy: A systematic review and pairwise meta-analysis. Anim. Health Res. Rev 20:217-228. https://doi.org/10.1017/S1466252319000306.

Woolford, M. W., J. H. Williamson, A. M. Day, and P. J. A. Copeman. 1998. The prophylactic effect of a teat sealer on bovine mastitis during the dry period and the following lactation. N. Z. Vet. J. 46:12-19. https://doi.org/10.1080/00480169.1998.36044.

\section{ORCIDS}

S. McDougall ৫ https://orcid.org/0000-0002-9865-0532

J. Williamson (• https://orcid.org/0000-0003-1691-6315

J. Lacy-Hulbert (ㄴ) https://orcid.org/0000-0002-9847-1294 